\title{
Counter Electrode Impact on Quantum Dot Solar Cell Efficiencies
}

\author{
P. Naresh Kumar, ${ }^{\dagger}$ Ankita Kolay, ${ }^{\dagger}$ S. Krishna Kumar, ${ }^{\dagger}$ Prabir Patra, ${ }^{\ddagger}, \S$ Ashish Aphale, ${ }^{\ddagger}$ \\ Avanish Kumar Srivastava," and Melepurath Deepa* ${ }^{\dagger}$ \\ ${ }^{\dagger}$ Department of Chemistry, Indian Institute of Technology Hyderabad, Kandi, Sangareddy 502285, Telangana, India \\ ${ }^{\ddagger}$ Department of Biomedical Engineering and ${ }^{\S}$ Department of Mechanical Engineering, University of Bridgeport, Bridgeport, \\ Connecticut 06604, United States \\ "CSIR-National Physical Laboratory, Dr. K. S. Krishnan Road, New Delhi 110012, India
}

Supporting Information

ABSTRACT: The counter electrode (CE), despite being as relevant as the photoanode in a quantum dot solar cell (QDSC), has hardly received the scientific attention it deserves. In this study, nine CEs (single-walled carbon nanotubes (SWCNTs), tungsten oxide $\left(\mathrm{WO}_{3}\right)$, poly $(3,4-$ ethylenedioxythiophene) (PEDOT), copper sulfide $\left(\mathrm{Cu}_{2} \mathrm{~S}\right)$, candle soot, functionalized multiwalled carbon nanotubes (FMWCNTs), reduced tungsten oxide $\left(\mathrm{WO}_{3-x}\right)$, carbon fabric (C-Fabric), and $\mathrm{C}-\mathrm{Fabric} / \mathrm{WO}_{3-x}$ ) were prepared by using low-cost components and facile procedures. QDSCs were fabricated with a $\mathrm{TiO}_{2} / \mathrm{CdS}$ film which served as a common photoanode for all CEs. The power conversion efficiencies (PCEs) were 2.02, 2.1, 2.79, 2.88, 2.95, 3.78, 3.66, 3.96, and 4.6\%, respectively, and the incident photon to current conversion efficiency response was also found to complement the PCE response. Among all $\mathrm{CEs}$ employed here, $\mathrm{C}-\mathrm{Fabric} / \mathrm{WO}_{3-x}$ outperforms all the other CEs, for the synergy between $\mathrm{C}$-Fabric and $\mathrm{WO}_{3-x}$ comes to the fore during cell operation. The low sheet resistance of $\mathrm{C}$-Fabric and its high surface area due to the meshlike morphology enables high $\mathrm{WO}_{3-x}$ loading during electrodeposition, and the good electrocatalytic activity of $\mathrm{WO}_{3-x}$, the very low overpotential, and its high electrical conductivity that facilitate electron transfer to the electrolyte are responsible for the superior $\mathrm{PCE}$. $\mathrm{WO}_{3}$-based electrodes have not been used until date in QDSCs; the ease of fabrication of $\mathrm{WO}_{3}$ films and their good chemical stability and scalability also favor their application to QDSCs. Futuristic possibilities for other novel composite CEs are also discussed. We anticipate this study to be useful for a well-rounded development of high-performance QDSCs.

KEYWORDS: quantum dots, liquid junction, solar cells, counter electrode, efficiency

\section{INTRODUCTION}

Recent advances in quantum dot solar cells (QDSCs) have propelled them to the forefront of photovoltaic research, for power conversion efficiencies (PCEs) in excess of $11 \%$ have been achieved by Zhong's group. ${ }^{1}$ The use of passivation layers of $\mathrm{SiO}_{2}$ and $\mathrm{ZnS}$ in the photoanode to minimize excited electron recombination has emerged as a powerful strategy for reducing photocurrent losses and boosting PCEs in these reports. ${ }^{2}$ The current impressive forays made in designing photoanodes for improved efficiencies provides the stimulus to revisit the other half of the cell, namely, the counter electrode (CE) and how it impacts PCEs. The electrolyte typically employed in a QDSC is a polysulfide ion based solution or gel. The prerequisites that a potential CE needs to satisfy to be employable in a QDSC are listed here. (i) The CE should be highly electrocatalytic and catalyze the reduction of the polysulfide species to the polysulfide anion. (ii) It should not undergo photodecomposition. (iii) It should be chemically compatible with the polysulfide electrolyte and should not dissolve in the electrolyte. (iv) It should be a good electron conductor conducive to fast electron transfer to the electrolyte. (v) It should have a work function in the range of $4.3-5.3 \mathrm{eV}$. (vi) Ideally, it should be inexpensive, nontoxic, and earthabundant as well. (vii) It should be optically transparent, if the QDSC is to be illuminated from the front side (optional). A variety of materials which fulfill some or most of the abovedescribed requirements have been employed in QDSCs with reasonable success in the past. Metal sulfides such as $\mathrm{NiS}, \mathrm{CoS}$, $\mathrm{CuS}, \mathrm{Cu}_{2} \mathrm{~S}$, and $\mathrm{PbS}$, conducting polymers such as poly $(3,4-$ ethylenedixoythiophene) (PEDOT) and poly(pyrrole) (PPy), metals such as $\mathrm{Pt}, \mathrm{Au}$, and $\mathrm{Ag}$, and graphitic nanostructures such as multiwalled carbon nanotubes (MWCNTs), reduced graphene oxide (rGO), and single-walled carbon nanotubes (SWCNTs) have been used as CEs in QDSCs. ${ }^{3-7}$ Composites of $\mathrm{Cu}_{2} \mathrm{~S} / \mathrm{RGO}, \mathrm{Au} / \mathrm{MWCNTs}, \mathrm{Pt} / \mathrm{RGO}$, and others have also

Received: July 20, 2016

Accepted: September 22, 2016

Published: September 22, 2016 
been attempted, ${ }^{8-10}$ in view of the increased catalytic activity of the composites compared to the pristine material.

Some interesting examples are summarized here. The superior electrocatalytic activity of $\mathrm{Cu}_{2} \mathrm{ZnSn}\left(\mathrm{S}_{0.5} \mathrm{Se}_{0.5}\right)_{4}$ nanocrystals compared to that of Pt resulted in a higher PCE of $3.01 \%$ for a QDSC prepared with the multielement chalcogenide as a $\mathrm{CE}$ and $\mathrm{TiO}_{2} / \mathrm{CdS} / \mathrm{CdSe} / \mathrm{ZnS}$ as the photoanode. ${ }^{11}$ A cell with a $\mathrm{RGO}-\mathrm{Cu}_{2} \mathrm{~S}$ composite film as a $\mathrm{CE}$ and a $\mathrm{TiO}_{2} / \mathrm{CdS} / \mathrm{CdSe} / \mathrm{ZnS}$ film as the photoanode significantly outperformed an equivalent cell with $\mathrm{Pt}$ as a $\mathrm{CE}{ }^{5}$ The RGO- $\mathrm{Cu}_{2} \mathrm{~S}$ composite showed a lower charge transfer resistance $\left(R_{\mathrm{ct}}\right)$, lower overpotential for polysulfide reduction, and a higher exchange current density; thus, the corresponding cell exhibited an increased PCE of $4.4 \%$ compared to that of the Pt-based cell, which delivered a PCE of $1.6 \% .^{5}$ Isabella et al. have used the $\mathrm{Pt}, \mathrm{Au}, \mathrm{Cu}_{2} \mathrm{~S}$ obtained by brass treatment, and $\mathrm{Cu}_{2} \mathrm{~S}$ deposited on conducting glass via spray as CEs. With $\mathrm{TiO}_{2} / \mathrm{CdS}$ as the photoanode, they achieved an efficiency of $1.75 \%$ for the $\mathrm{Cu}_{2} \mathrm{~S} /$ glass as $\mathrm{CE}{ }^{12}$ With $\mathrm{PbS}$ as a $\mathrm{CE}$ and a $\mathrm{TiO}_{2} / \mathrm{CdSe}$ film as the photoanode, the ensuing cell yielded a PCE of $3.01 \%$ compared to a PCE of $0.75 \%$ with Pt as the CE. ${ }^{13}$ The use of $\mathrm{PbS}$ as a $\mathrm{CE}$ resulted in reduced internal resistances, recombination rates, and concentration gradients in the electrolyte, which enhanced the short circuit current density $\left(J_{\text {sc }}\right)$ and the fill factor (FF) in comparison to those of the cell with $\mathrm{Pt}$ as a CE. ${ }^{13}$ For cells with $\mathrm{ZnO} / \mathrm{ZnSe} / \mathrm{CdSe}$ nanocables as the photoanode and hierarchical $\mathrm{Cu}_{2} \mathrm{SnS}_{3}$ and $\mathrm{Cu}_{1.8} \mathrm{~S}$ microspheres as CEs, PCEs of 3.65 and $4.06 \%$ were attained. ${ }^{14}$ In another work, metal sulfides ( $\mathrm{CuS}, \mathrm{CoS}, \mathrm{NiS}$, and $\mathrm{PbS}$ ) were supported on ITO porous films and employed in cells with $\mathrm{TiO}_{2} / \mathrm{CdS} / \mathrm{CdSe} / \mathrm{ZnS}$ films as the photoanodes, and the highest performance was obtained for a cell with $\mathrm{CuS}$ as a CE, with a PCE of $1.47 \%{ }^{7}$ Jun et al. studied five CEs, Pt, graphite, carbon soot, $\mathrm{Cu}_{2} \mathrm{~S}$, and $\mathrm{rGO}$, and compared cell performances, but their study was confined to very few CEs and limited characterization. ${ }^{15}$

Considering the spectacular trajectory of PCE improvements achieved in QDSCs by innovative photoanode design ${ }^{1,16,17}$ stems the need to screen a plethora of different types of CEs to identify CEs that are most efficient at playing a complementary role in augmenting the performance of the photoanode. Besides being cheap and easily processable at low temperature, an ideal CE should permit fast electron transfer to the electrolyte to minimize the reduction overpotential, which in turn reduces electron back-transfer from the photoanode to the electrolyte, thus maximizing PCE. While there are reviews on counter electrodes for QDSCs, ${ }^{18-20}$ to the best of our knowledge there are no reports wherein a broad spectrum of different types of CEs have been employed and evaluated (in terms of cell performances) in equivalent QDSCs with same photoanode and the same hole-transport layer. Novel CEs are typically studied in isolation. ${ }^{4,21,22}$ A study of a range of CEs can provide a deeper understanding of how counter electrodes control PCEs of QDSCs. To bridge this gap, here we present an elaborate study on the use of (i) high surface area carbon in the form of MWCNTs and SWCNTs supported on FTO, candle soot, and carbon fabric composed of a meshlike network of carbon fibers, (ii) a metal sulfide, $\mathrm{Cu}_{2} \mathrm{~S}$, (iii) a transition metal oxide, $\mathrm{WO}_{3}$ (and variants), and (iv) a conducting polymer, PEDOT, as CEs in QDSCs. All these CEs were used in cells with a $\mathrm{TiO}_{2} / \mathrm{CdS}$ film as the photoanode and a sodium sulfide solution as an electrolyte. The materials used for CEs were either cheaply procured or prepared economically at lab-scale.
Such a study furnished interesting insights into how a CE controls the QDSC performance, which we believe will be useful for researchers working on QDSCs, as it will help in developing efficient CEs suitable for a given QDs sensitized electrode. Future directions for developing high-performance CEs are also discussed.

\section{EXPERIMENTAL SECTION}

Preparation of $\mathrm{TiO}_{2} / \mathrm{CdS}$ Photoanode and Storage. Prior to applying $\mathrm{TiO}_{2}$ paste, $\mathrm{F}: \mathrm{SnO}_{2}$-coated optically transparent conductive glass substrates (FTO) were cleaned in a soap solution followed by sonication in ethanol and acetone 1:1 v/v mixture by using an ultrasonic bath. Finally, isopropyl alcohol was used for cleaning the substrates. Then, $5 \mathrm{mg}$ of $\mathrm{TiO}_{2}-\mathrm{P} 25$ (free gift from Evonik) was transferred into a clear solution of acetyl acetone $(7.5 \mathrm{~mL})$ and water $(2.5 \mathrm{~mL})$ and sonicated for $10 \mathrm{~min}$. To this, 1 drop of Triton X-100 surfactant (Sigma-Aldrich) was added to prevent $\mathrm{TiO}_{2}$ particle aggregation. Furthermore, this paste was sonicated in a water bath for 10 more minutes, and then the paste was applied onto the cleaned FTO substrates by doctor blading technique. These films were heated to $60{ }^{\circ} \mathrm{C}$ followed by sintering at $500{ }^{\circ} \mathrm{C}$. This first layer of $\mathrm{TiO}_{2}$ is mesoporous, and it is conducive to deposit the CdS QDs. A second layer of $\mathrm{TiO}_{2}$ was applied onto the first layer, to increase the QD loading, and the same annealing procedure was followed. Finally these films were placed in a $40 \mathrm{mM}$ aqueous $\mathrm{TiCl}_{4}$ solution at $70{ }^{\circ} \mathrm{C}$ for 25 min, rinsed in deionized water, and sintered at $500{ }^{\circ} \mathrm{C}$ for another 30 min (i) to reduce the surface defects and (ii) for better interparticle connectivity so as to minimize the shunt paths. CdS QDs were grown onto the $\mathrm{TiO}_{2}$ surface by the successive ionic layer absorption and reaction (SILAR) technique. To do this, $0.1 \mathrm{M}$ sodium sulfide and 0.1 $\mathrm{M}$ cadmium acetate solutions in methanol were taken separately. The $\mathrm{TiO}_{2}$ film was first immersed in the cadmium precursor solution, then immersed in the sulfide solution. The QDs growth time was fixed to 2 $\mathrm{min}$. The film was kept for 2 min exactly in each precursor solution and followed by rinsing in methanol. After each rinse, the films were dried in a hot air oven for $2 \mathrm{~min}$. This was considered 1 SILAR cycle for CdS QD growth. A 5\% aqueous $\mathrm{HCl}$ solution was used to remove the CdS QDs which were inadvertently deposited over FTO instead of $\mathrm{TiO}_{2}$. The electrode was subjected to 6 more cycles of SILAR, and the $\mathrm{TiO}_{2} / \mathrm{CdS}$ photoanode was obtained. The $\mathrm{TiO}_{2} / \mathrm{CdS}$ films were used after storage in dark for 10 days at $45^{\circ} \mathrm{C}$.

Preparation of CEs and Cell Fabrication. $\mathrm{WO}_{3} /$ FTO. Tungsten metal powder ( $1 \mathrm{~g}$, Sigma-Aldrich) was added slowly to a hydrogen peroxide $(30 \%$, Merck, $10 \mathrm{~mL})$ solution. The solution was aged for $7 \mathrm{~h}$ at room temperature to allow the exothermic dissolution of the metal power in $\mathrm{H}_{2} \mathrm{O}_{2}$. Once the effervescence subsided, the solution was centrifuged, and the decant solution was collected. This pale yellow solution of polyperoxotungstic acid was drop-cast on FTO substrates, and the films were heated at for $100{ }^{\circ} \mathrm{C}$ for $2 \mathrm{~h}$. The peroxo-groups decompose upon heating to ensure $\mathrm{WO}_{3}$ films were deposited over FTO substrates, which were stored in a desiccator.

SWCNTS/FTO. SWCNTs procured from Cheap Tubes, Inc., were functionalized by using a procedure described in detail in a previous report. ${ }^{23}$ First, $1 \mathrm{mg}$ of the functionalized SWCNTs were dispersed in ultrapure water $(5 \mathrm{~mL})$ by ultrasonication for $10 \mathrm{~min}$. The resulting dispersion of SWCNTs was used as the medium for electrophoresis. Two precleaned FTO substrates were used as cathode and anode and immersed in the dispersion of SWCNTs. A constant dc potential of 30 $\mathrm{V}$ was applied across the electrodes for $3 \mathrm{~min}$. A black colored deposit was obtained on one of the two FTO substrates. The films were dried for $12 \mathrm{~h}$ in a hot-air oven at $60{ }^{\circ} \mathrm{C}$ and stored in a vacuum-filled desiccator.

PEDOT/FTO. A clear solution of $0.1 \mathrm{M}$ lithium trifluoromethanesulfonate or triflate $\left(\mathrm{LiCF}_{3} \mathrm{SO}_{3}\right), 1 \mathrm{M}$ camphor 10-sulfonic acid, and 0.1 $\mathrm{M}$ ethylenedioxythiophene (EDOT) in isopropyl alcohol $(10 \mathrm{~mL})$, all sourced from Sigma-Aldrich, was used as the precursor bath. PEDOT was electropolymerized from the monomer onto a precleaned FTO conducting substrate in a three-electrode configuration by using a $\mathrm{Pt}$ rod as the auxiliary electrode, a FTO substrate as the working 
Scheme 1. (a) Cartoon Illustrating the Working of a QDSC and (b) Photograph Showing All Counter Electrodes Used in $\operatorname{QDSCs}^{a}$

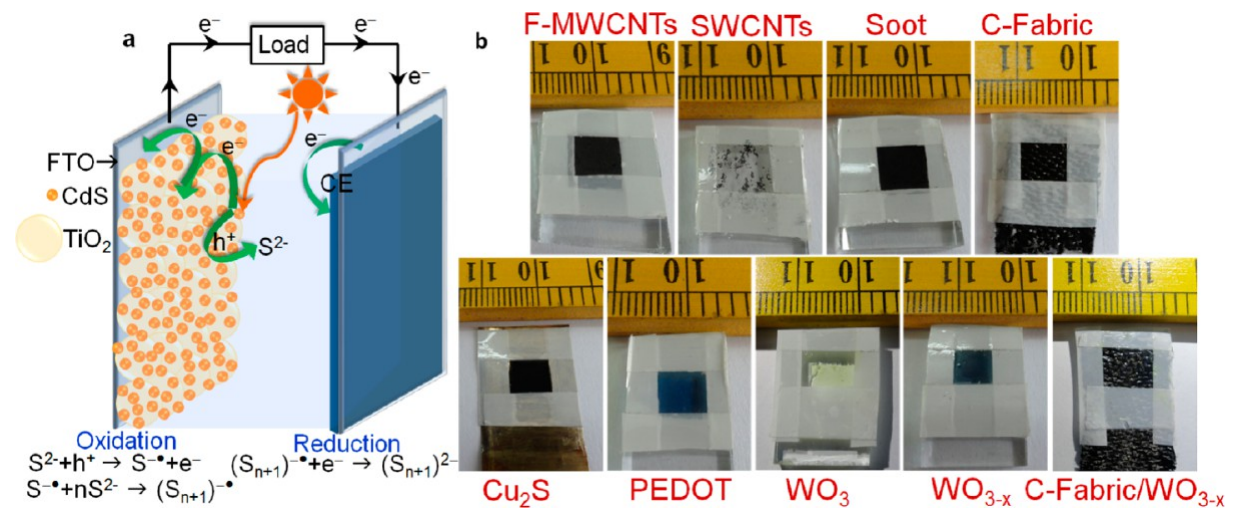

${ }^{a}$ In panel $\mathrm{b}$, the $\mathrm{C}$-Fabric based electrodes were glued to micro-slide glass plates (for mechanical support), and $\mathrm{Cu}_{2} \mathrm{~S}$ was deposited on a brass foil. All the remaining CE materials were deposited on FTO substrates.

electrode (WE), and $\mathrm{Ag} / \mathrm{AgCl} / \mathrm{KCl}$ as the reference electrode under potentiostatic conditions by applying a constant $\mathrm{dc}$ bias of $+0.8 \mathrm{~V}$ to the working electrode for $3 \mathrm{~min}$. A thick blue deposit of PEDOT was obtained over the FTO substrate, and the films were rinsed thoroughly in isopropanol, dried at room temperature in air, then stored in a desiccator.

$\mathrm{Cu}_{2} \mathrm{~S} /$ Brass Foil. $\mathrm{Cu}_{2} \mathrm{~S}$ was grown over a brass foil by using a wellestablished protocol involving the exposure of a brass foil to a polysulfide electrolyte solution, which yields a $\mathrm{Cu}_{2} \mathrm{~S}$ layer grown from the brass substrate. ${ }^{4} \mathrm{~A}$ brass foil with $99 \%$ purity was kept immersed in an aqueous concentrated $\mathrm{HCl}$ solution at $70{ }^{\circ} \mathrm{C}$ for an hour. The foil was then rinsed in ultrapure water and dried with a hot air gun. It was then immersed in an aqueous polysulfide solution $(1 \mathrm{M}$ sulfur $(S)+1$ $\mathrm{M} \mathrm{Na} \mathrm{N}_{2} \mathrm{~S}$ ) for $1 \mathrm{~min}$. The etched portion of brass foil turned black, indicating the formation of cuprous sulfide. The $\mathrm{Cu}_{2} \mathrm{~S} / \mathrm{brass}$ film was washed in ultrapure water, dried in air at room temperature, and then stored in a vacuum desiccator.

Soot/FTO. A precleaned FTO glass substrate was exposed to the luminous zone of a candle flame for $5 \mathrm{~s}$, and a uniform black soot deposit was obtained on the conducting surface. The excess deposit outside of the required geometric area was carefully wiped out using a tissue. The soot/FTO film was stored in a desiccator.

F-MWCNTS/FTO. To a solution of $1: 3 \mathrm{v} / \mathrm{v} \mathrm{H}_{2} \mathrm{SO}_{4} / \mathrm{HNO}_{3}$ (each of 6 M strength, $60 \mathrm{~mL}$ ) was added $200 \mathrm{mg}$ of MWCNTs, and the suspension was refluxed at $90{ }^{\circ} \mathrm{C}$ for $10 \mathrm{~h}$. After cooling to room temperature, the reaction mixture was diluted with ultrapure water $(100 \mathrm{~mL})$ and then washed with ultrapure water until the supernatant liquid showed a neutral $\mathrm{pH}$. Using ashless fast filter paper ( $\varnothing: 150$ $\mathrm{mm}$ ), the resulting brown solid, referred to as functionalized (F)MWCNTs was collected, dried at room temperature, and dispersed in water by sonication for $2 \mathrm{~h}$. F-MWCNTs were electrophoretically deposited onto the FTO substrate in a two-electrode cell with two FTO substrates serving as WE and CE. A dc bias of $30 \mathrm{~V}$ was applied for $3 \mathrm{~min}$, and the F-MWCNTs-coated substrates were dried at $60{ }^{\circ} \mathrm{C}$ in a hot-air oven and then stored in a desiccator.

C-Fabric. Carbon (C)-Fabric was procured from Alibaba Pvt., Ltd. It was cut into the desired dimensions using a pair of scissors and cleaned with acetone before use.

C-Fabric/ $\mathrm{WO}_{3-x}$. Polyperoxotungstic acid (mentioned in the preparation of $\mathrm{WO}_{3} \mathrm{CE}$ ) was used as a precursor solution. A threeelectrode setup comprising C-Fabric of desired dimensions as the WE, a Pt rod as the $\mathrm{CE}$, and $\mathrm{Ag} / \mathrm{AgCl} / \mathrm{KCl}$ as the reference electrode was used. A fixed dc bias of $-0.5 \mathrm{~V}$ was applied for $5 \mathrm{~min}$ to the C-Fabric or FTO (WE), and blue films of $\mathrm{WO}_{3-x}$ formed over the C-Fabric or FTO by the cathodic reduction of the polyperoxotungstate species to $\mathrm{WO}_{3-x}$.

The photographs of all nine counter electrodes used in this study are shown in Scheme 1, which also gives an illustration of the working of a QDSC. QDSCs were assembled by using $\mathrm{TiO}_{2} / \mathrm{CdS}$ photoanodes, which were fabricated under exactly the same conditions to enable a reliable comparison of their solar to electrical power conversion efficiencies with the diverse counter electrodes. The area of photoanodes was maintained to lie in the range of $8-10 \mathrm{~mm}^{2}$. A cavity was created using a Parafilm on the photoanode, which served as a spacer, and a $0.1 \mathrm{M}$ sodium sulfide solution in water and methanol $(3: 7 \mathrm{v} / \mathrm{v})$ solution was dropped in the cavity using a dropper. The $\mathrm{TiO}_{2} / \mathrm{CdS}$ and the $\mathrm{CE}$ films were then sandwiched by placing the $\mathrm{CE}$ film over the $\mathrm{TiO}_{2} / \mathrm{CdS} /$ Parafilm assembly, with their active areas facing each other. Binder clips were used to hold the cell assembly together, and the cells were used for photovoltaic measurements.

Characterization Techniques. Surface morphology of CE materials were examined using a field-emission scanning electron microscope (Carl Zeiss Supra 40 FE-SEM). Transmission electron microscopy (TEM) was performed on a Tecnai G2 FEI operating at an accelerating voltage of $300 \mathrm{kV}$. Samples were dispersed in acetone and then transferred onto carbon-coated copper grids, and the solvent was evaporated at room temperature prior to use. XRD patterns of the CE materials were recorded on a PANalytical, X'PertPRO instrument with $\mathrm{Cu} \mathrm{K} \alpha(\lambda=1.5406 \AA)$ radiation. A Bruker Senterra dispersive Raman microscope spectrometer with a $532 \mathrm{~nm}$ laser excitation was used to measure the vibration modes of the counter electrode materials. Photoluminescence (PL) spectra of the photoactive materials were recorded using an assembled system comprising a M266-I unit (monochromator, with continuum light source with housing, light collection system with toroidal optics and a filter wheel with 5 colored glass filters) and an Avaspec-2048 spectrometer detector to collect the data. A suitable filter was utilized during the measurement. Fluorescence lifetime was deducted by time-correlated single photon counting (TCSPC) method with a Horiba Jobin Yvon data station HUB functioning in the TCSPC mode. Excitation source was a nano LED, pulsed at $370 \mathrm{~nm}$ with a $1 \mathrm{MHz}$ repetition rate; the pulse duration was 1.3 ns. Light-scattering Ludox solution (colloidal silica) was used to acquire the instrument response function (prompt). Horiba Jobin Yvon DAS6 fluorescence decay analysis software was used to fit the model function (biexponential decays) to the experimental data with appropriate correction for the instrument response. Current versus potential $(I-V)$ data of QDSCs were recorded using a Newport Oriel 3A solar simulator with a Keithley model 2420 digital source meter. A $450 \mathrm{~W}$ xenon arc lamp was the light source which provided a light intensity of $100 \mathrm{~mW} \mathrm{~cm}$ of air mass (AM) 1.5G illumination; the spatial uniformity of irradiance was confirmed by calibrating with a $2 \mathrm{~cm} \times 2 \mathrm{~cm}$ Si reference cell and reaffirmed with a Newport power meter. Incident photon to current conversion efficiency (IPCE) versus wavelength data were recorded using a Quantum Efficiency Measurement System, Oriel IQE-200, capable of measurements compliant to ASTM E1021-06. The light 

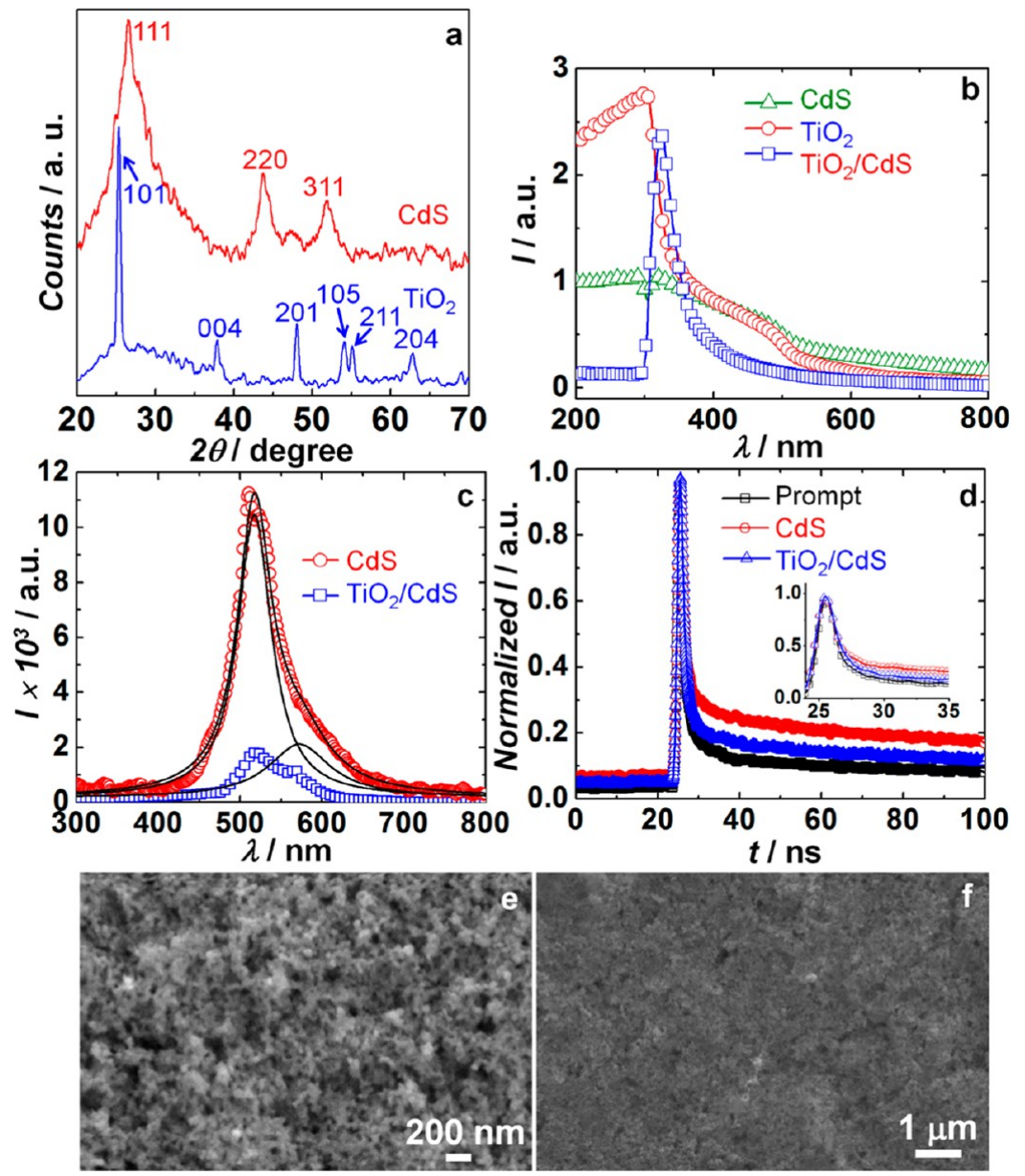

Figure 1. (a) XRD patterns of $\mathrm{TiO}_{2}$ and $\mathrm{CdS}$ and (b) absorption spectra of $\mathrm{TiO}_{2}, \mathrm{CdS}$, and $\mathrm{TiO}_{2} / \mathrm{CdS}$. (c) Fluorescence spectra of CdS/glass (deconvoluted, represented by solid lines) and $\mathrm{TiO}_{2} / \mathrm{CdS}\left(\lambda_{\mathrm{ex}}=370 \mathrm{~nm}\right)$ and $(\mathrm{d})$ emission decay plots of $\mathrm{CdS} /$ glass and $\mathrm{TiO} \mathrm{O}_{2} / \mathrm{CdS}\left(\lambda_{\mathrm{ex}}=370 \mathrm{~nm}\right.$ and $\lambda_{\mathrm{em}}=515 \mathrm{~nm}$ ). FE-SEM images of (e) $\mathrm{TiO}_{2}$ and (f) $\mathrm{TiO}_{2} / \mathrm{CdS}$ films.

source was a $250 \mathrm{~W}$ quartz tungsten halogen lamp, the monochromator path length was $1 / 8 \mathrm{M}$, and the spot size was a 1 $\mathrm{mm} \times 2.5 \mathrm{~mm}$ rectangle at focus. Linear sweep voltammograms (LSV) and electrochemical impedance spectra (EIS) were recorded on an Autolab PGSTAT 302N equipped with a frequency response analyzer and a NOVA 1.9 software.

\section{RESULTS AND DISCUSSION}

Aspects of the Photoanode. Prior to studying the different CEs, the photoanode was characterized. The structural and optical characteristics of the photoanode are presented in Figure 1. The XRD plot of $\mathrm{TiO}_{2}$ (Figure 1a), shows peaks at $2 \theta$ $=25.3,37.8,48.1,53.9,55.1$, and $62.7^{\circ}$, which match with the (101), (004), (201), (105), (211) and (204) planes of the tetragonal body centered lattice and anatase structure of $\mathrm{TiO}_{2}$, in accordance with Powder Diffraction File (PDF) no. 894921 (Joint Committee on Powder Diffraction Standards (JCPDS), 1953). The diffractogram of CdS (Figure 1a) shows broad peaks at $2 \theta=26.4,43.0$, and $51.9^{\circ}$, corresponding to the (111), (220), and (311), reflections of the face-centered cubic $(f c c)$ lattice of CdS, as per PDF no. 890440 (JCPDS, 1996). The UV-visible absorbance spectrum of $\mathrm{TiO}_{2}$ (Figure 1b) shows that it has a flat and negligible absorption in the visible region and shows an onset of absorbance at $390 \mathrm{~nm}$. The $\lambda_{\max }$ for pristine $\mathrm{TiO}_{2}$ is observed at $320 \mathrm{~nm}$. However, pristine CdS shows a relatively flat absorption profile in the UV region. Therefore, in the $\mathrm{TiO}_{2} / \mathrm{CdS}$ film, a mixed effect is observed, where the overall absorbance increases in the UV region (due to $\mathrm{TiO}_{2}$ ), but the distinct peak (as observed in $\mathrm{TiO}_{2}$ ) is now reduced to a flat but high-intensity broad signal (due to $\mathrm{CdS}$ ), peaking at $304 \mathrm{~nm}$. For the $\mathrm{TiO}_{2} / \mathrm{CdS}$ film, a broad absorption peak is observed in the visible region, with the onset at $520 \mathrm{~nm}$, indicative of the fact that CdS QDs have diffused into the pores of the $\mathrm{TiO}_{2}$ film, and it is this portion of the visible spectrum which $(<520 \mathrm{~nm})$ which is harvested by the QDSC when this film is employed as a photoanode.

From the absorption edges, the optical band gaps $\left(E_{\mathrm{g}}\right)$ of $\mathrm{TiO}_{2}$ and $\mathrm{CdS}$ were estimated to be 3.2 and $2.38 \mathrm{eV}$ from the relation $E_{\mathrm{g}}=1240 / \lambda(\mathrm{nm})$. To study the charge transfer mechanism, the photoluminescence spectra of pristine $\mathrm{CdS}$ (deposited on glass) and $\mathrm{TiO}_{2} / \mathrm{CdS}$ films were recorded at an excitation wavelength of $370 \mathrm{~nm}$ (Figure 1c). The PL spectrum of pristine CdS QDs shows a very broad emission, spanning from 450 to $620 \mathrm{~nm}$, with a $\lambda_{\max }$ at $519 \mathrm{~nm}$. The peak was deconvoluted into two components: The first emission peak at $517 \mathrm{~nm}$ is primarily attributed to band edge excitation, and the second peak at $574 \mathrm{~nm}$ is attributed to the presence of surface defects on QDs. The luminescence of CdS is quenched to $\sim 17 \%$ of its original magnitude ongoing to the $\mathrm{TiO}_{2} / \mathrm{CdS}$ film, and this is due to fast transfer of photogenerated electrons from the conduction band (CB) of $\mathrm{CdS}$ to the $\mathrm{CB}$ of $\mathrm{TiO}_{2}$. This was further confirmed by emission decay analysis. The excited electron lifetimes of $\mathrm{CdS}$ alone and along with $\mathrm{TiO}_{2}$ were 


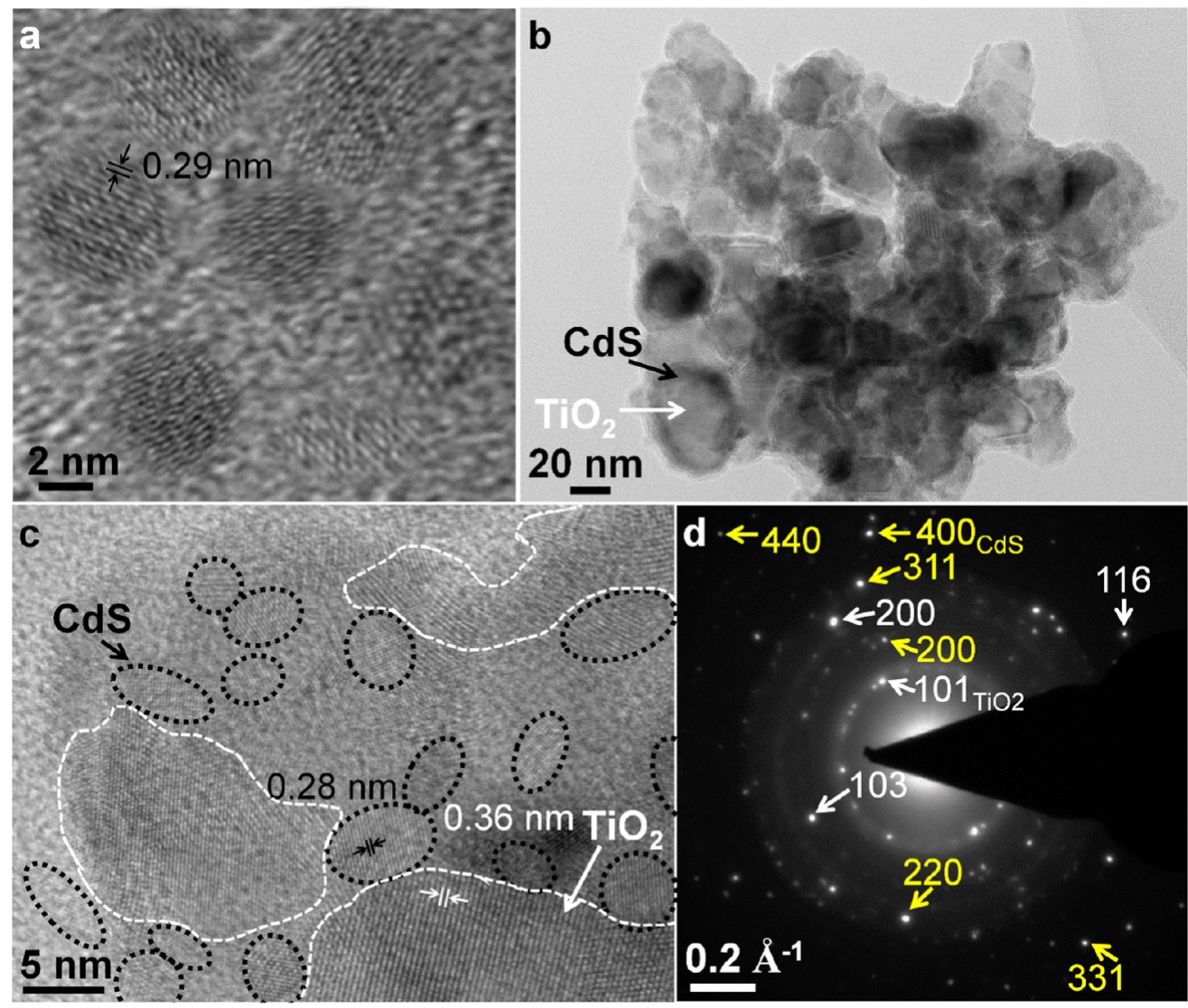

Figure 2. (a) Lattice scale image of pristine CdS QDs, (b) TEM image, (c) lattice scale image, and (d) SAED pattern of a $\mathrm{TiO}_{2} / \mathrm{CdS}_{\text {assembly. }}$

estimated by fitting the decay plots obtained from the TCSPC method. The decay curves accurately fitted into biexponential functions, and the average electron lifetimes $(<\tau>)$ were determined and are listed in Table S1.

$$
\begin{aligned}
& I=B_{1} \exp \left(-t / \tau_{1}\right)+B_{2} \exp \left(-t / \tau_{2}\right) \\
& <\tau>=\sum B_{\mathrm{i}} \tau_{i}^{2} / \sum B_{\mathrm{i}} \tau_{i}
\end{aligned}
$$

In eqs 1 and 2, $B_{1}$ and $B_{2}$ are the amplitude coefficients of the excited electron lifetimes $\left(\tau_{1}\right.$ and $\left.\tau_{2}\right)$ and $t$ is the time after LED excitation. For CdS QDs, the short-lived component of $0.25 \mathrm{~ns}$ is assigned to the electron-hole $\left(\mathrm{e}^{-}-\mathrm{h}^{+}\right)$recombination at the band edge, and the long-lived component of $21.9 \mathrm{~ns}$ is attributed to electron trapping in the midgap defect states. When CdS QDs are tethered to $\mathrm{TiO}_{2}$, the average electron lifetime was further reduced; it decreases from $21.6 \mathrm{~ns}$ (pristine $\mathrm{CdS})$ to $2.76 \mathrm{~ns}\left(\mathrm{TiO}_{2} / \mathrm{CdS}\right)$. The short-lived component for $\mathrm{TiO}_{2} / \mathrm{CdS}$ retains almost the same magnitude: The value is $0.33 \mathrm{~ns}$ and is the time taken for photoexcited electrons to recombine at the band edge, but the long-lived component decreases significantly to $4.48 \mathrm{~ns}$. This is attributed to the time taken by electrons to cascade into the intragap trap states formed at the interface of $\mathrm{TiO}_{2}$ and $\mathrm{CdS}$ QDs. Our assignments comply well with those reported by Shalom et al. for $\mathrm{TiO}_{2} / \mathrm{CdS}$ QDs based films. ${ }^{24}$ The FE-SEM images of $\mathrm{TiO}_{2}$ and $\mathrm{TiO}_{2} /$ CdS films are shown in Figure 1d,e, respectively. The $\mathrm{TiO}_{2}$ film is characterized by a granular morphology with globular interlinked particles with voids or pores between. The pores show a rather large distribution in size; they vary from 5 to 70 $\mathrm{nm}$ in dimensions. When the $\mathrm{TiO}_{2}$ film is exposed to the $\mathrm{Cd}^{2+}$ and $S^{2-}$ solutions during the growth of CdS by SILAR, the CdS
QDs are deposited in the pores of the oxide film, thus ensuring intimate contact between the oxide and QDs, which is beneficial for fast charge transfer during solar cell working. The micrograph of the $\mathrm{TiO}_{2} / \mathrm{CdS}$ film also continues to be granular, for the QDs tend to aggregate in the absence of a capping agent.

The lattice scale TEM image of pristine CdS quantum dots is shown in Figure 2a. The image shows the presence of discrete QDs, approximately 3-6 $\mathrm{nm}$ in size. The interfringe separation is about $0.29 \mathrm{~nm}$, which matches very well with an interplanar spacing of $2.91 \AA$, corresponding to the $(200)$ plane of CdS with a $f c c$ lattice (PDF no. 652887, JCPDS, 1925). The TEM image of $\mathrm{TiO}_{2} / \mathrm{CdS}$ assembly is shown in Figure $2 \mathrm{~b}$. The image shows mingling nanoparticles of $\mathrm{TiO}_{2}$ with indistinctive shapes which are decorated with CdS QDs. The grain boundaries are fuzzy for both the QDs and $\mathrm{TiO}_{2}$ at low magnification. The corresponding lattice scale image of the $\mathrm{TiO}_{2} / \mathrm{CdS}$ assembly (Figure 2c) shows large nanoparticles of $\mathrm{TiO}_{2} 20-40 \mathrm{~nm}$ in size, represented by the dashed lines. The $\mathrm{TiO}_{2}$ particles are composed of distinct lattice fringes with an interfringe distance of $0.36 \mathrm{~nm}$, which is close to $d=3.51 \AA$, corresponding to the (101) plane of $\mathrm{TiO}_{2}$ with a body-centered tetragonal structure (PDF no. 894921, JCPDS, 1953). The $\mathrm{TiO}_{2}$ nanoparticles are juxtaposed with the CdS QDs; in some portions, there is significant overlapping of lattice fringes, indicating that the QDs are tethered to the $\mathrm{TiO}_{2}$ scaffold. Discrete CdS QDs are still observed in the film, and these are ensconced in dotted ellipses in the image. The size of the CdS QDs varies from 3 to $7 \mathrm{~nm}$. The selected area electron diffraction (SAED) pattern of the $\mathrm{TiO}_{2} / \mathrm{CdS}$ assembly (Figure 2d) shows a diffused ring pattern superimposed with bright and dull spots. The spots were 
indexed to (101), (103), (200), and (116) planes of the tetragonal structure of $\mathrm{TiO}_{2}$, for these spots matched with $d=$ $3.51,2.42,1.90$, and $1.37 \AA$. Bright spots from the crystalline CdS QDs were indexed to the (200), (220), (311), (400), (331), and (440) planes of the $f c c$ structure. The $d$-values for these planes were $2.9,2.05,1.74,1.44,1.34$, and $1.04 \AA$. The coexistence of spots from $\mathrm{TiO}_{2}$ and $\mathrm{CdS}$ in the SAED pattern confirms a good mixing of the two components.

Counter Electrode Characterization. Raman Spectroscopic Analysis. In this study, the films which were employed for use as CEs in QDSCs are F-MWCNTs, soot, SWCNTs, CFabric, $\mathrm{WO}_{3}, \mathrm{WO}_{3-x}$ supported on C-Fabric, $\mathrm{Cu}_{2} \mathrm{~S}$, and PEDOT. The Raman spectra of the CEs are presented in Figure 3. The molecular vibrations of the carbonaceous

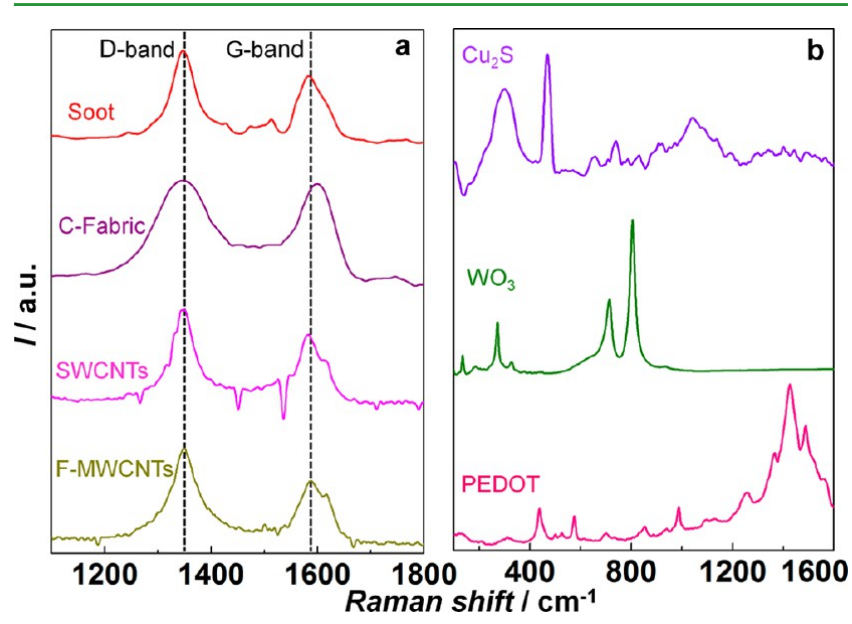

Figure 3. Raman spectra of (a) soot, C-fabric, SWCNTs, and FMWCNTs, and (b) $\mathrm{Cu}_{2} \mathrm{~S}, \mathrm{WO}_{3}$, and PEDOT.

materials are compared in Figure $3 \mathrm{a}$, and this has been accomplished by comparing their $I_{\mathrm{D}} / I_{\mathrm{G}}$ values. The $\mathrm{D}$-band in carbon based materials arises from the out-of-plane vibrations or ring-breathing modes of carbon atoms due to structural defects (atomic vacancies or presence of oxygen-containing functional groups along the carbon framework) or the measure of deviation from the perfect graphitic structure. The G-band originates from the in-plane vibrational modes of $\mathrm{sp}^{2}$-hybridized carbon atoms. The D- and G- band positions and the corresponding $I_{\mathrm{D}} / I_{\mathrm{G}}$ ratios are provided in Table 1 . In the

Table 1. Raman Data of Carbon Nanostructures

\begin{tabular}{lccc}
\multicolumn{1}{c}{ CE } & D-band $\left(\mathrm{cm}^{-1}\right)$ & G-band $\left(\mathrm{cm}^{-1}\right)$ & $I_{\mathrm{D}} / I_{\mathrm{G}}$ \\
soot & 1347 & 1584 & 1.123 \\
SWCNTs & 1345 & 1583 & 1.654 \\
F-MWCNTs & 1350 & 1588 & 2.109 \\
C-Fabric & 1346 & 1598 & 2.282 \\
\hline
\end{tabular}

table, the carbon-based materials are arranged in the increasing order of the proportion of defects. Among these, the $I_{\mathrm{D}} / I_{\mathrm{G}}$ ratio is the highest for the C-Fabric, 2.28, and this high concentration of defects in C-Fabric possibly forms during the synthetic process for large mechanical forces are applied to yield lengthy C-fibers. This is responsible for the increased defects on its surface. Despite this defect concentration, a high PCE is achieved for the cells containing C-Fabric or C-Fabric/ $\mathrm{WO}_{3-x}$ as CEs, for this disadvantage is offset by (i) its extremely low sheet resistance, $8-15 \Omega \mathrm{cm}^{-2}$, lower than that of pristine FTO
(30 $\Omega \mathrm{cm}^{-2}$ ), which serves as the current collector for the bulk of the CE materials used in this study and (ii) the high effective surface (catalytic) area offered by the meshlike structure of the intertwined C-fibers in the C-Fabric. The $I_{\mathrm{D}} / I_{\mathrm{G}}$ ratio is surprisingly the smallest for soot and comparable for SWCNTs, which have slightly higher values, in that order. The low $I_{\mathrm{D}} / I_{\mathrm{G}}$ ratio of 1.12 obtained for soot is ascribed to the high preparation temperature of $1000{ }^{\circ} \mathrm{C}$, which perhaps results in the formation of interlinked carbon particles with minimum defects and without the formation of any oxygenated functionalities.

The Raman spectrum of $\mathrm{Cu}_{2} \mathrm{~S}$ (Figure $3 \mathrm{~b}$ ) shows a narrow intense peak at $470 \mathrm{~cm}^{-1}$, which is assigned to the vibrational (stretching) mode of the covalent bond existing between two sulfur atoms, and a broad peak at about $290 \mathrm{~cm}^{-1}$ is attributed to the $\mathrm{Cu}-\mathrm{S}$ bond vibration. ${ }^{25}$ For $\mathrm{WO}_{3}$, the bands at 267 and $322 \mathrm{~cm}^{-1}$ correspond to the $\mathrm{O}-\mathrm{W}-\mathrm{O}$ bending modes of the bridging oxygen, and the peaks at 709 and $809 \mathrm{~cm}^{-1}$ represent symmetric and asymmetric $\mathrm{O}-\mathrm{W}-\mathrm{O}$ stretching vibrations. These peaks are very close to the wavenumbers of the four strongest modes of crystalline $\mathrm{WO}_{3}{ }^{26,27}$ The spectrum of $\mathrm{WO}_{3-x}$ did not show any peaks, probably because of high amorphicity, and therefore is not shown here. In the case of PEDOT, Raman peaks at 1488, 1426 (strong), 1360, and 1256 $\mathrm{cm}^{-1}$ were observed, and these are assigned to the asymmetric $(\mathrm{C}=\mathrm{C})$ stretching, symmetric $\mathrm{C}_{\alpha}=\mathrm{C}_{\beta}(-\mathrm{O})$ stretching, $\mathrm{C}_{\beta}-\mathrm{C}_{\beta}$ stretching, and $\mathrm{C}_{\alpha}-\mathrm{C}_{\alpha^{\prime}}$ (inter-ring) stretching vibrational modes. ${ }^{28,29}$ Additional medium intensity peaks observed at 988,576 , and $436 \mathrm{~cm}^{-1}$ are attributed to the oxyethylene ring deformation modes. $^{28,29}$ No peak was observed around 1700 $\mathrm{cm}^{-1}$, which indicated that monomer is not overoxidized during PEDOT formation.

XRD Studies. XRD patterns of CE materials are displayed in Figure 4. C-Fabric, C-Fabric/ $\mathrm{WO}_{3-x}$, F-MWCNTs, SWCNTs,

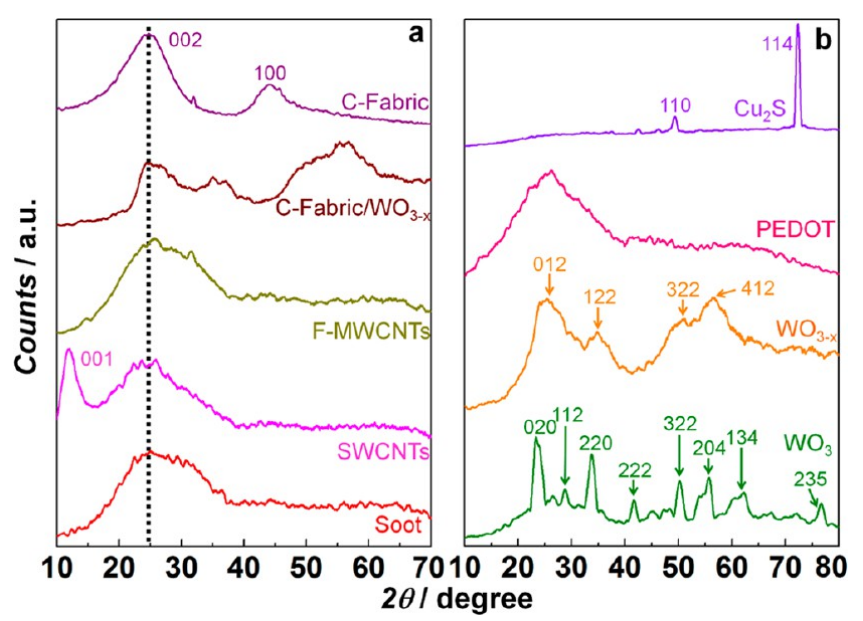

Figure 4. XRD patterns of (a) C-Fabric, C-Fabric/ $\mathrm{WO}_{3-x}$, FMWCNTs, SWCNTs, and soot and (b) $\mathrm{Cu}_{2} \mathrm{~S}$, PEDOT, $\mathrm{WO}_{3-x}$, and $\mathrm{WO}_{3}$.

and soot show characteristic broad humps at $2 \theta=24.7^{\circ}$ corresponding to the interplanar $d$-spacing of $3.60 \AA$ (Figure 4a). The latter peak is attributed to the (002) plane of graphite, in concurrence with PDF no. 75-1621 (JCPDS, 1997). The interlayer spacing between the graphitic sheets is enlarged in the other carbon nanostructures, possibly due to the presence of functional groups. SWCNTs are characterized by an 

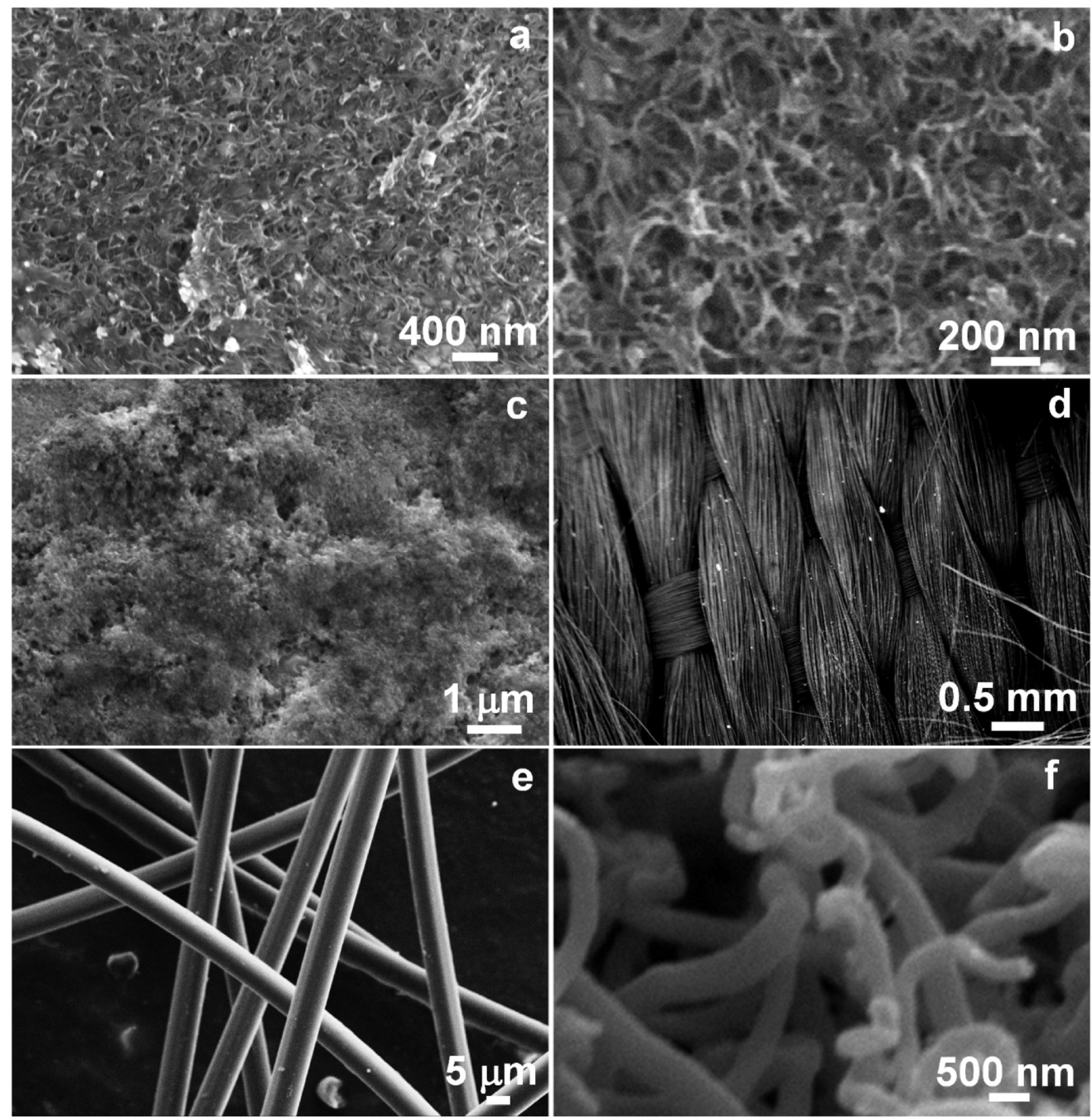

Figure 5. FE-SEM images of (a and b) F-MWCNTs, (c) soot, (d and e) C-Fabric, and (f) SWCNTs.

additional peak at $2 \theta=12.0^{\circ}$, corresponding to $d=7.36 \AA$, which agrees with $d=8.8 \AA$ obtained for GO by Gao et al. in a previous report. ${ }^{30}$ Authors attributed this peak to the enhanced separation between graphitic layers, induced by the presence of bulky function groups in between the layers. In another report, carbon nanostructures with $2 \theta$ peaks $<15^{\circ 31}$ were associated with interlayer separation corresponding to the (001) plane; therefore, this attribute is observed in SWCNTs here. C-Fabric also shows a very broad peak at $2 \theta=44.02^{\circ}$, corresponding to $d$ $=2.05 \AA$, and it represents the $\mathrm{C}-\mathrm{C}$ atomic separation in the carbon nanostructure. For the C-Fabric/ $\mathrm{WO}_{3-x}$ composite, the contributions from $\mathrm{WO}_{3-x}$ are superimposed on the contributions from the underlying C-Fabric, so reliable assignments (from carbon) could not be made. $\mathrm{Cu}_{2} \mathrm{~S}$ produced a pattern with peaks at $2 \theta=49.5,72.5$, and $87.4^{\circ}$, and these correspond to $d=1.85,1.31$, and $1.12 \AA$, which align with the (110), (114), and (220) planes of the hexagonal (primitive) structure, based on PDF no. 892670 (JCPDS, 1963, Figure 4b). ${ }^{32}$ Reduced $\mathrm{WO}_{3}$ or $\mathrm{WO}_{3-x}$ is almost amorphous, for it shows three extremely broad peaks at $2 \theta=24.7,34.9$, and $56.8^{\circ}$, which correspond to $d=3.56,2.57$, and $1.62 \AA$, and these match with the (012), (122), and (412) planes of orthorhombic $\mathrm{WO}_{3}$ (PDF no. 894479, JCPDS, 1999). $\mathrm{WO}_{3}$ is polycrystalline, for it shows multiple peaks in its XRD pattern, and prominent peaks are observed at $2 \theta=23.64,28.53,33.84,41.76,50.06,55.34$,
61.7 , and $76.5^{\circ}$, corresponding to $d=3.75,3.13,2.64,2.16$, $1.82,1.66,1.50$, and $1.24 \AA$ which match with (020), (112), (220), (222), (322), (204), (134), and (235) planes of the orthorhombic crystal structure of $\mathrm{WO}_{3}$, as per PDF no. 894479 (JCPDS, [year]).

Electron Microscopy Studies. FE-SEM images of the CE materials are shown in Figures 5 and 6. The images of FMWCNTs (Figure 5a,b) show a meshlike structure composed of the functionalized CNTs where the fibrillar structures are retained but the discrete character of the CNTs is not visible. Furthermore, a few particulate structures appear to be superimposed over the tubes in some regions, indicating that the tubes get ruptured to accommodate the oxygen-containing functional groups (i.e., $\mathrm{C}=\mathrm{O}, \mathrm{C}-\mathrm{O}-\mathrm{C}, \mathrm{C}-\mathrm{OH}$, etc.) during acid treatment. The micrograph of candle soot (Figure 5c) reveals a dense particulate morphology, with a few pores interspersed in between. The particles have no unique shape, and they are completely aggregated along multiple length scales. Since the soot was directly adsorbed from the candle flame to the FTO substrate, the soot deposit has a wavy texture and appears to be thicker along the crests and thinner along the troughs. Pristine C-Fabric has a woven matlike structure (Figure $5 \mathrm{~d}, \mathrm{e}$ ); it is made up of carbon fibers which are neatly arranged into a webbing that imparts the nettinglike appearance to the C-Fabric as a whole. The image of SWCNTs (Figure 5f) 

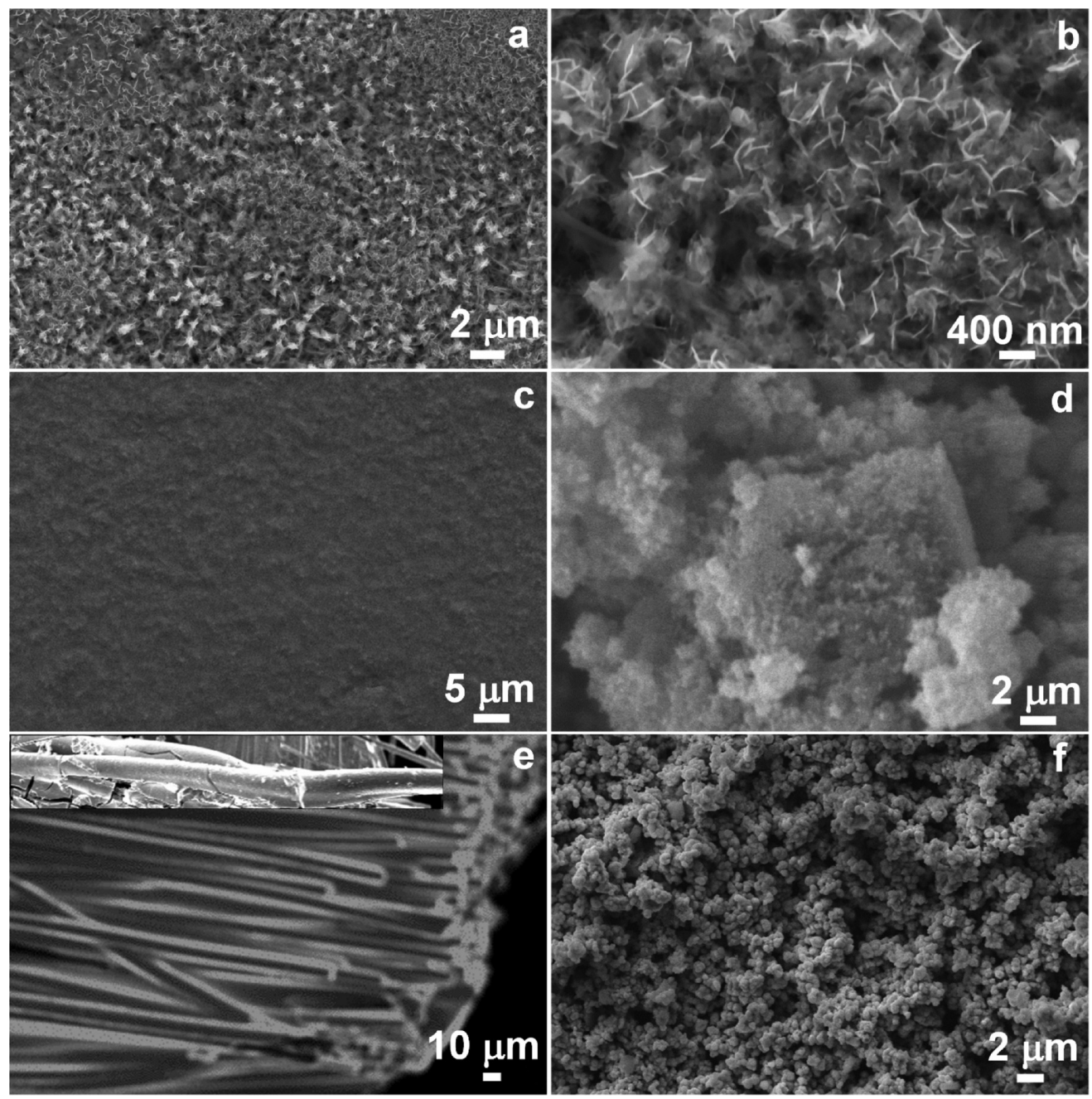

Figure 6. FE-SEM images of ( $\mathrm{a}$ and $\mathrm{b}$ ) $\mathrm{Cu}_{2} \mathrm{~S}$, (c) $\mathrm{WO}_{3}$, (d) $\mathrm{WO}_{3-x}$, (e) C-Fabric/ $\mathrm{WO}_{3-x}$, with inset showing $\mathrm{WO}_{3-x}$ coated C-fibers, and (f) PEDOT.

reveals the nanotubes to be well-dispersed, despite the chemical modification, and there are no carbonaceous particles seen to be flanking the tubes, indicating that the single-walled structures are not severely impacted by the acid treatment and sonication.

The morphology of $\mathrm{Cu}_{2} \mathrm{~S}$ (Figure 6a,b) shows flaky petal-like shapes which are uniformly distributed across the surface of the brass foil, and they appear to be perpendicularly oriented with respect to the brass foil. Although there is some degree of agglomeration of the flaky shapes, they still seem to be discrete enough to offer a high catalytic area for the reduction of the oxidized polysulfide ions (from the electrolyte) during solar cell operation when the $\mathrm{Cu}_{2} \mathrm{~S} /$ brass film is employed as a $\mathrm{CE}$ therein. The morphology of $\mathrm{WO}_{3}$ (Figure 6c) is almost featureless for the image shows the oxide film to be made up of a compactly packed network of particles of indistinctive shapes, with hardly any pores separating them. The micrograph of $\mathrm{WO}_{3-x}$ (Figure 6d) comprises connected micrometer-sized particles separated by pores. The micrograph of C-Fabric/ $\mathrm{WO}_{3-x}$ (Figure 6e) shows the fibers of C-fabric to be coated with particles of $\mathrm{WO}_{3-x}$; the thick deposits of $\mathrm{WO}_{3-x}$ tethered to the C-Fabric has two distinctive attributes. (i) Due to the reduced nature of the oxide (in $\mathrm{WO}_{3-x}$ ), the electronic conductivity is expected to higher than that of $\mathrm{WO}_{3} / \mathrm{FTO}$, and (ii) unlike the planar FTO, the interlaced structure of C-Fabric which the $\mathrm{WO}_{3-x}$ particles attach to has a higher surface area. As a consequence, the solar cell performance of the cell with $\mathrm{C}$ Fabric/ $/ \mathrm{WO}_{3-x}$ as the $\mathrm{CE}$ is expected to be better than that of cells with $\mathrm{FTO} / \mathrm{WO}_{3}, \mathrm{FTO}$, or C-Fabric as the CEs. The image of PEDOT (Figure 6f) reveals interconnected particles of cauliflower-like shapes, with large pores in-between. This morphology is typical of electropolymerized PEDOT films. ${ }^{33}$

$J-V$ Characteristics and Spectral Response. QDSCs were assembled with $\mathrm{TiO}_{2} / \mathrm{CdS}$ films as the photoanodes and nine different CEs. A solution of $0.1 \mathrm{M} \mathrm{Na}_{2} \mathrm{~S}$ was used as the electrolyte in all the cells. The current density $(J)$ versus voltage $(V)$ plots for the QDSCs are presented in Figure 7a,b. The solar cell parameters for all the cells, short circuit current density $\left(J_{\mathrm{SC}}\right)$, open circuit voltage $\left(V_{\mathrm{OC}}\right)$, fill factor $(\mathrm{FF})$ and $\operatorname{PCE}(\eta)$, are summarized in Table 2 . The average values of PCEs are also included in the Table 2; for each cell configuration, five cells were considered. The average parameters are furnished in Table S2. The magnitudes of all the solar cell parameters are not only governed by the photoanode and the electrolyte but are also strongly dependent on the counter electrode. Across the entire spectrum of cells studied herein, $V_{\mathrm{oc}}$ is found to vary between 0.72 and $1.07 \mathrm{~V}$. The lowest $V_{\text {oc }}$ is obtained for a cell with $\mathrm{Cu}_{2} \mathrm{~S}$ as the CE. The highest $V_{\mathrm{OC}}$ is achieved for the cell with $\mathrm{WO}_{3}$ as the $\mathrm{CE}$. The $V_{\mathrm{OC}}$ of the cell with C-Fabric/ $\mathrm{WO}_{3-x}$ as the $\mathrm{CE}$ comes in at a 

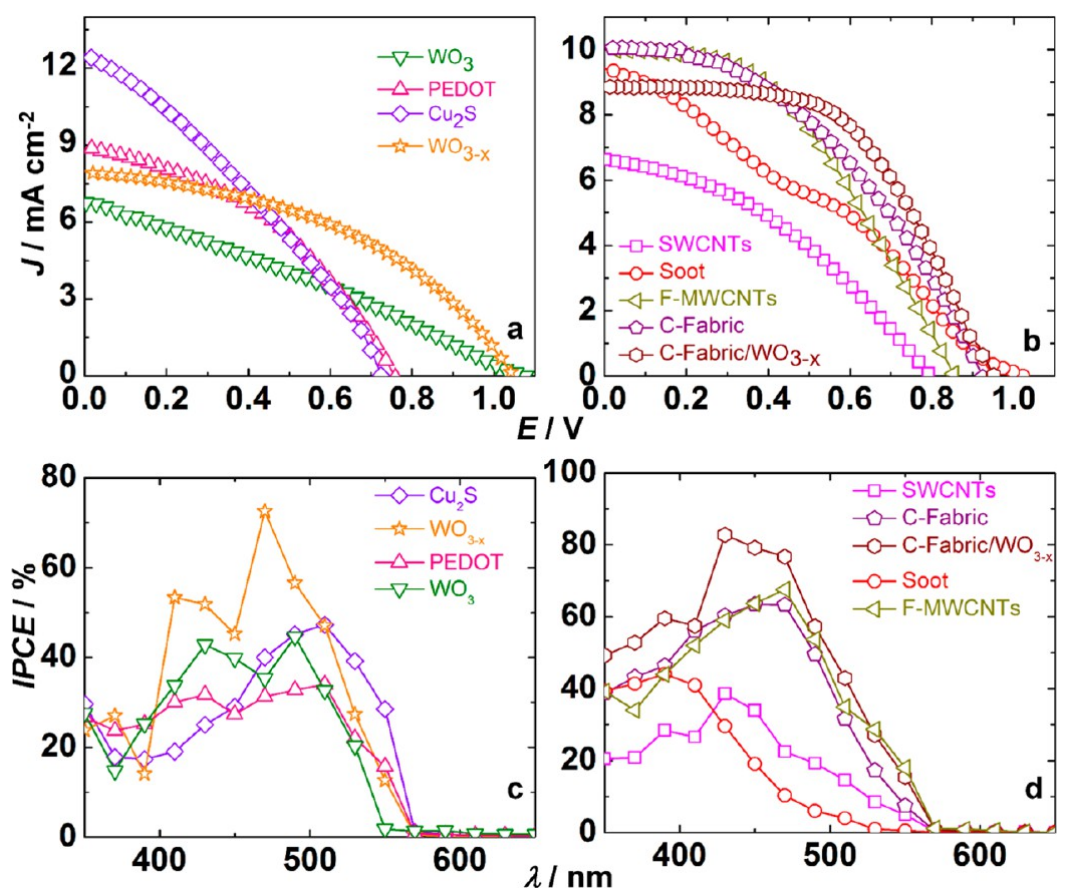

Figure 7. (a and b) $J-V$ characteristics (recorded under 1 sun irradiance $\left(100 \mathrm{~mW} \mathrm{~cm}^{-2}\right)$ ) and (c and d) IPCE versus wavelength plots of QDSCs with $\mathrm{TiO}_{2} / \mathrm{CdS}$ films as the photoanodes, $0.1 \mathrm{M} \mathrm{Na}_{2} \mathrm{~S}$ solutions as electrolytes, and with different counter electrode films.

Table 2. Solar Cell Parameters of Cells with $0.1 \mathrm{M} \mathrm{Na}_{2} \mathrm{~S}$ Electrolyte, with $\mathrm{TiO}_{2} / \mathrm{CdS}$ as the Photoanode and Exposed Cell Area $\left(0.08-0.10 \mathrm{~cm}^{2}\right)$ under 1 sun Illumination (100 $\mathrm{mW} \mathrm{cm}^{-2}$ ) with the Listed Counter Electrodes

\begin{tabular}{|c|c|c|c|c|c|}
\hline counter electrode & $\begin{array}{c}J_{\mathrm{sc}} \\
\left(\mathrm{mA} \mathrm{cm}^{-2}\right)\end{array}$ & $\begin{array}{l}V_{\text {oc }} \\
(\mathrm{V})\end{array}$ & FF & $\begin{array}{c}\text { PCE } \\
(\eta, \%)\end{array}$ & $\begin{array}{c}\text { average } \eta \\
\text { (\%) }\end{array}$ \\
\hline SWCNTs & 6.59 & 0.791 & 38.75 & 2.021 & 1.92 \\
\hline $\mathrm{WO}_{3}$ & 6.81 & 1.077 & 28.63 & 2.1 & 2.0 \\
\hline PEDOT & 8.892 & 0.759 & 41.40 & 2.79 & 2.76 \\
\hline $\mathrm{Cu}_{2} \mathrm{~S}$ & 12.56 & 0.723 & 31.70 & 2.88 & 2.757 \\
\hline soot & 8.842 & 0.965 & 34.50 & 2.954 & 2.93 \\
\hline $\mathrm{WO}_{3-x}$ & 7.9 & 1.04 & 44.54 & 3.66 & 3.338 \\
\hline F-MWCNTs & 9.99 & 0.852 & 44.38 & 3.78 & 3.618 \\
\hline C-Fabric & 10.04 & 0.924 & 42.78 & 3.97 & 3.893 \\
\hline C-Fabric/ $/ \mathrm{WO}_{3-x}$ & 8.86 & 0.951 & 51.51 & 4.6 & 4.45 \\
\hline
\end{tabular}

close second $(1.04 \mathrm{~V})$. All the cells with carbonaceous CEs exhibit reasonably high values of $V_{\mathrm{OC}}$, in the range of $\sim 0.80-$ $0.96 \mathrm{~V}$. On comparing the $J_{\mathrm{SC}}$ values achieved for the cells, the highest $J_{\mathrm{SC}}$ was observed for the cell with $\mathrm{Cu}_{2} \mathrm{~S} /$ brass as the $\mathrm{CE}$ $\left(12.56 \mathrm{~mA} \mathrm{~cm}^{-2}\right)$. This performance is due to the high catalytic area offered by the $\mathrm{Cu}_{2} \mathrm{~S}$ petal-like (or flake-like) shapes, which enables efficient reduction of polysulfide species and thus leads to more charge generation. The cell containing C-Fabric shows the second highest $J_{\mathrm{SC}}\left(10.04 \mathrm{~mA} \mathrm{~cm}^{-2}\right)$, and this again is due to its low electrical resistance. The cells with other electrodes show $J_{\mathrm{SC}}$ values that lie in the range of $6.5-10 \mathrm{~mA} \mathrm{~cm}$. Besides $V_{\mathrm{OC}}$ and $J_{\mathrm{SC}}$, a high $\mathrm{FF}$ also contributes to maximizing PCE of a QDSC. A high FF is generally obtained for a cell if the shunt resistance is high and the series resistance is low. The highest $\mathrm{FF}$ is delivered by the cell with $\mathrm{C}-\mathrm{Fabric} / \mathrm{WO}_{3-x}$ as the $\mathrm{CE}(\sim 51.5)$, indicating that the series resistance is minimum and the shunt resistance is maximum among all cells here. This high FF translates to the highest PCE of $4.6 \%$ for the champion cell among all cells studied in this report. The cell with C-Fabric delivers a PCE of $3.97 \%$, closely followed by the cell with F-
MWCNTs as the CE (3.78\%). By examining all the PCEs in Table 2, it is evident that carbonaceous structures as CEs are very effective in producing cells with high efficiencies. The CFabric $/ \mathrm{WO}_{3-x}$ electrode outperforms all other CEs, due to the synergy between the characteristics of $\mathrm{C}$-Fabric and $\mathrm{WO}_{3-x}:(\mathrm{i})$ low sheet resistance of $\mathrm{C}$-Fabric and its high surface area due to the nettinglike morphology, which allows high $\mathrm{WO}_{3-x}$ loading during electrodeposition, and (ii) the good catalytic activity of $\mathrm{WO}_{3-x}$ and its high electrical conductivity that facilitate electron transfer to the electrolyte during cell operation.

We also ran a comparison with literature values. Radich et al. fabricated a $\mathrm{Cu}_{2} \mathrm{~S} / \mathrm{rGO}$ composite and used it as a $\mathrm{CE}$ with CdS/CdSe QDs photoanode in a QDSC and achieved a PCE of $4.4 \% .^{5}$ Deng et al. screen-printed $\mathrm{Cu}_{2} \mathrm{~S}$ QDs and conductive carbon on FTO, and when it was employed as a CE in a CdS/ CdSe based QDSC, the PCE of the device was $3.71 \% .^{34} \mathrm{Zhao}$ et al. compared cell performances with $\mathrm{Cu}_{2} \mathrm{~S} / \mathrm{FTO}$ and $\mathrm{Cu}_{2} \mathrm{~S} /$ brass and $\mathrm{Pt}$ as CEs. They obtained PCEs of 5.21, 5.41, and $1.68 \%$, respectively. ${ }^{4}$ The use of carbon cloth as a CE is reported in dye-sensitized solar cells (DSSCs) and not in QDSCs by other researchers. Tathavadekar et al. fabricated a conducting carbon cloth from a cellulose fabric from a complex pyrolysis route and then obtained PCEs of 5.8 and $7 \%$ for DSSCs with C-cloth and Pt/FTO as CEs. ${ }^{35}$ The perfromance is reversed in our study, for we found that in QDSCs with CFabric the PCE was higher than that achieved with Pt. Similarly, $\mathrm{WO}_{3}$ has also not been used in QDSCs but has beeen used in DSSCs. Li et al. used $\mathrm{NH}_{3}$-treated $\mathrm{WO}_{3}$ as a CE in a DSSC, and it delivered a PCE of $5.9 \%$, which was comparable to the PCE of the cell with Pt as CE (6.0\%). ${ }^{36}$ Here, we observed that with $\mathrm{WO}_{3} / \mathrm{FTO}$ and $\mathrm{WO}_{3-x} / \mathrm{FTO}$ as CEs in QDSCs the PCEs are higher at 2.1 and $3.66 \%$ compared to that obtained with $\mathrm{Pt}$ as the CE $(1.69 \%)$ reiterating that other catalytic materials are better performers compared to $\mathrm{Pt}$ in QDSCs and thus contrasting the trends observed in DSSCs. With carbon soot as $\mathrm{CE}$ and $\mathrm{TiO}_{2} / \mathrm{CdS}$ as the photoanode, the authors in ref 15 

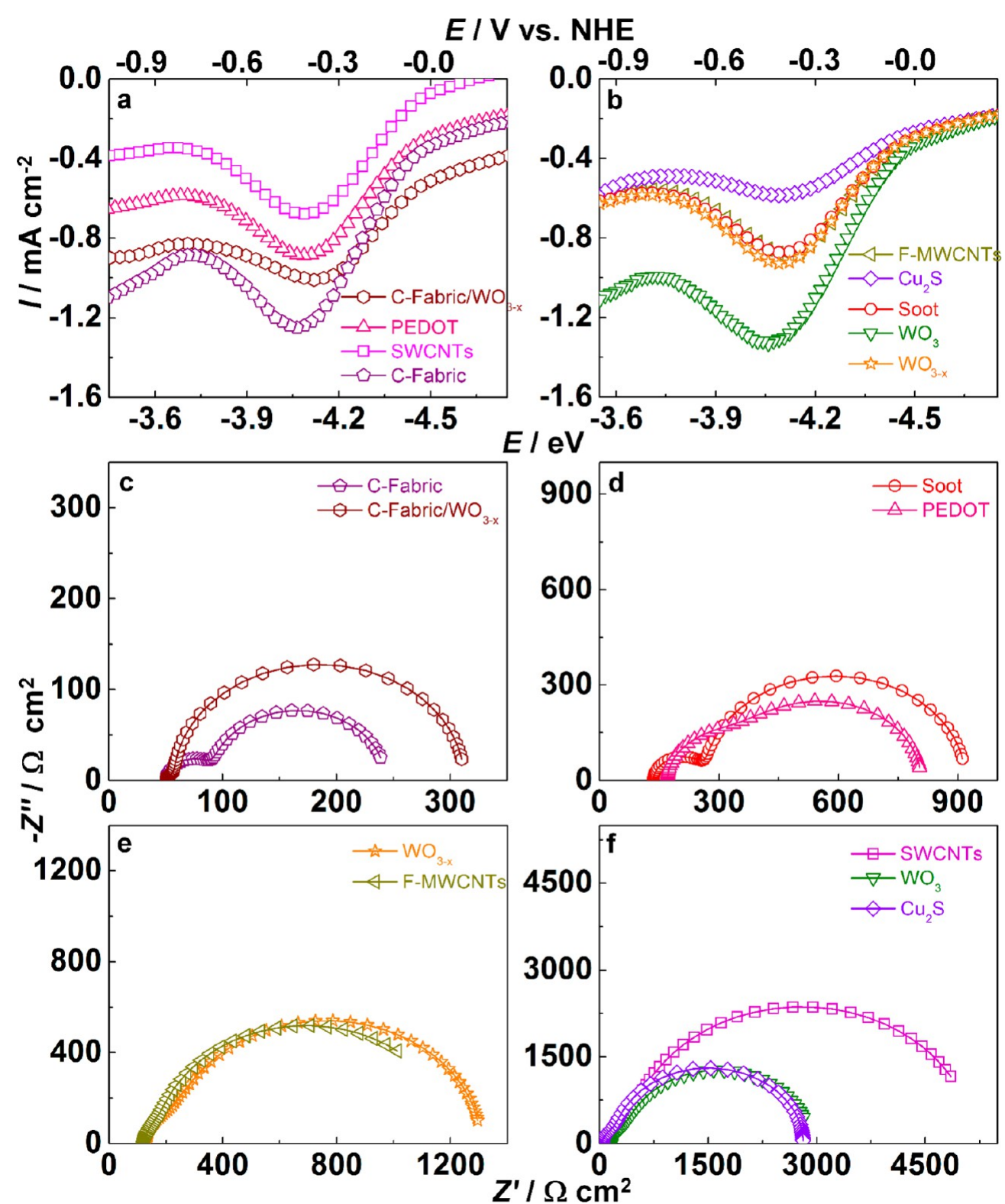

Figure 8. ( $\mathrm{a}$ and $\mathrm{b}$ ) Linear sweep voltammograms of different $\mathrm{CEs}$ (as working electrodes) in a $0.02 \mathrm{M} \mathrm{Na}_{2} \mathrm{~S}$ solution in an ultrapure water/ methanol solution $(3: 7 \mathrm{v} / \mathrm{v})$ containing $0.2 \mathrm{M} \mathrm{KCl}$ as supporting electrolyte. A Pt rod was used as the counter electrode, and an $\mathrm{Ag} / \mathrm{AgCl} / \mathrm{KCl}$ was used as a reference electrode. The potential in volts on the abscissa was converted to eV, by using the relation $\left(E(\mathrm{eV})=-\left(x \mathrm{~V}\left(\mathrm{vs} \mathrm{Ag} / \mathrm{Ag}^{+}\right)+0.197\right.\right.$ $\mathrm{V}+4.5))$. ( $\mathrm{c}-\mathrm{f})$ Nyquist plots of QDSCs with $\mathrm{TiO}_{2} / \mathrm{CdS}$ films as the photoanodes, $0.1 \mathrm{M} \mathrm{Na}_{2} \mathrm{~S}$ solutions as electrolytes, and different counter electrode films.

reported a PCE of $1.16 \%$, which is lower than the value obtained here with soot (2.95\%). For a cell with MWCNTs as the $\mathrm{CE}$ and $\mathrm{TiO}_{2} / \mathrm{CdSe} / \mathrm{ZnS}$ as the photoanode, a PCE of $2.39 \%$ was obtained. ${ }^{37}$ Yeh et al. compared the performances of QDSCs with three conducting polymers as CEs, namely, poly(thiophene) (PT), poly(pyrrole) (PPy), and PEDOT, and achieved PCEs of $0.09,0.41$, and $1.16 \%$, respectively. ${ }^{38}$ In the present work, the PCE of the champion cell with PEDOT as the $\mathrm{CE}$ is $2.79 \%$. A more detailed literature survey on solar cell parameters is provided in Table S3.

The spectral response or IPCE versus wavelength curves of QDSCs with different CEs are shown in Figure 7c,d. The IPCE values are the highest in the $320-520 \mathrm{~nm}$ wavelength range for the cell with $\mathrm{C}$-Fabric/ $\mathrm{WO}_{3-x}$ as $\mathrm{CE}$, which is in line with the highest $\mathrm{PE}$ achieved for this cell. The maximum IPCE exhibited by the cell withC-Fabric/ $/ \mathrm{WO}_{3-x}$ as the $\mathrm{CE}$ is $82 \%$ at $430 \mathrm{~nm}$.
The response is comparable for the cells with F-MWCNTs and $\mathrm{C}$-Fabric as the CEs, with slight variations, which also matches with the minor differences in their PCEs. The cells with other electrodes show lower values of IPCE in comparison with the cells with the aforesaid CEs. As expected, the cell with SWCNTs as the CE shows the lowest values of IPCEs in the visible region.

Redox Potential and EIS Studies. For fast electron transfer to the polysulfide radical in the electrolyte at the counter electrode, the CE should ideally offer a low overpotential. The overpotential $(\eta)$ required to drive the reaction at a certain current density $J$ gives rise to a charge transfer resistance $\left(R_{\mathrm{CT}}=\right.$ $\eta / J)$, which acts as a series resistance in the solar cell. ${ }^{39}$ In order to evaluate the electrocatalytic activities of the CE films for the reduction of polysulfide, LSV plots were recorded for the CE films (serving as working electrodes) in a $0.02 \mathrm{M} \mathrm{Na}_{2} \mathrm{~S}$ in a 
methanol/water solution containing $0.2 \mathrm{M} \mathrm{KCl}$ as the supporting electrolyte and $\mathrm{Pt}$ as the auxiliary electrode. The potential in volts was also converted to energy in $\mathrm{eV}$. The standard redox potential of $\mathrm{S}_{n}{ }^{2-} / \mathrm{S}^{2-}$ is $-0.6 \mathrm{~V}$ (versus normal hydrogen electrode or NHE), which is $-3.9 \mathrm{eV}$ versus vacuum. The LSV curves of the various CEs are presented in Figure $8 \mathrm{a}, \mathrm{b}$, and all the curves show a broad reduction peaks in the range of -3.7 to $-4.3 \mathrm{eV}$. CEs such as $\mathrm{C}-\mathrm{Fabric} / \mathrm{WO}_{3-x}$, CFabric, and $\mathrm{WO}_{3-x}$ show the least overpotentials, as their redox potentials are very close to the standard reduction potential of $\mathrm{S}_{n}{ }^{2-} / \mathrm{S}^{2-}$ redox couple. A high magnitude of reductive peak current density is also indicative of a high electrocatalytic activity. Table 3 furnishes the peak current densities and the

Table 3. Redox Potentials (from LSV Plots) and Charge Transfer Resistances (from EIS Plots) of Counter Electrode Films

\begin{tabular}{|c|c|c|c|}
\hline counter electrode & $E(\mathrm{~V}$ vs NHE) & $i_{\text {peak(red) }}\left(\mathrm{mA} \mathrm{cm}^{-2}\right)$ & $R_{\mathrm{CT}}(\Omega)$ \\
\hline SWCNTs & -0.617 & -0.676 & 247 \\
\hline $\mathrm{WO}_{3}$ & -0.612 & -1.327 & 202 \\
\hline PEDOT & -0.611 & -0.93 & 160 \\
\hline $\mathrm{Cu}_{2} \mathrm{~S}$ & -0.603 & -0.5809 & 152 \\
\hline soot & -0.600 & -0.866 & 125 \\
\hline $\mathrm{WO}_{3-x}$ & -0.586 & -0.8836 & 110 \\
\hline F-MWCNTs & -0.576 & -0.898 & 45 \\
\hline C-Fabric & -0.627 & -1.32 & 38 \\
\hline C-Fabric/ $/ \mathrm{WO}_{3-x}$ & -0.558 & -1.01 & 7 \\
\hline
\end{tabular}

redox potentials of the CEs. The C-Fabric/ $\mathrm{WO}_{3-x}$ electrode shows the least overpotential and the highest peak current density (during reduction), which is responsible for the highest PCE. Furthermore, tungsten is earth-abundant; tungsten oxide films are easily processable at low temperatures, can be fabricated with high uniformity over large areas using lowcost procedures, and are chemically stable as well. These aspects are advantageous in terms of long-term operation and scale-up for developing large area QDSCs. Since oxygen vacancy is a common feature of many metal oxides, the findings in this work can be extrapolated to other metal oxides (such as $\left.\mathrm{MoO}_{3-x}\right)$ and thus offer the possibility for developing composites with them.

To quantify the charge transfer resistance at the $\mathrm{CE} /$ electrolyte interface, a key factor that controls QDSC performance, EIS plots were recorded for QDSCs with the different CEs, under a white light irradiance of $20 \mathrm{~mW} \mathrm{~cm}^{-2}$, over a frequency range of $1 \mathrm{MHz}$ to $0.1 \mathrm{~Hz}$, and under an ac amplitude of $20 \mathrm{mV}$. All the plots shown in Figure $8 \mathrm{c}-\mathrm{f}$ contain a skewed arc extending into a broad semicircle, ongoing from high to low frequency. The first arc corresponds to the electron transfer between the polysulfide electrolyte and the CE interface, and the second semicircle represents the electron transport in the QD-sensitized $\mathrm{TiO}_{2}$ layer and the recombination process at the QD-sensitized $\mathrm{TiO}_{2}$ and electrolyte interface. For the cells with the configuration $\mathrm{TiO}_{2} / \mathrm{CdS}$ $\mathrm{S}_{n}{ }^{2-} / \mathrm{S}^{2-}-\mathrm{CE}$, the first semicircle in the corresponding Nyquist plot gave the charge transfer resistance $\left(R_{\mathrm{CT}}\right)$ at the $\mathrm{CE} / \mathrm{S}^{2-}$ interface. The $R_{\mathrm{CT}}$ magnitudes were deduced to be 247,202 , $160,152,125,110,45,38$, and $7 \Omega \mathrm{cm}^{2}$ corresponding to the SWCNTs, $\mathrm{WO}_{3}$, PEDOT, $\mathrm{Cu}_{2} \mathrm{~S}$, soot, $\mathrm{WO}_{3-x}$, F-MWCNTs, CFabric, and C-Fabric/ $\mathrm{WO}_{3-x}$ electrodes. The magnitude of $R_{\mathrm{CT}}$ was observed to be the least for the C-Fabric $/ \mathrm{WO}_{3-x}$ electrode, suggesting that electron transfer to the electrolyte from this $\mathrm{CE}$ is facile. C-Fabric and F-MWCNTs also had moderately low $R_{\mathrm{CT}}$ values. Superior solar cell performances of the cells based on these electrodes is also credited to their low $R_{\mathrm{CT}}$ values. SWCNTs show the highest $R_{\mathrm{CT}}$, which again, is another reason for the smallest PCE.

Future Directions. Considering the following prerequisites, high electrocatalytic activity, good chemical and photo stability, high electronic conductivity, cost effectiveness, and nontoxicity, there are many exciting possibilities for the development of yet unexplored CEs for use in QDSCs. Electropolymerized films of conducting polymers doped with carbon nanostructures (as dopants) can be attempted. These include yet unexplored composite films of poly(methylpyrrole) (PMP) doped with SWCNTs prefunctionalized with carboxylic groups (COO-), where PMP is a robust, cheap, chemically stable, roomtemperature processable (in film form), and a highly scalable conducting polymer and functionalized SWCNTs are good electronic conductors; therefore, the synergy between the properties of these two materials will come to the fore in the $\mathrm{PMP} / \mathrm{SWCNT}$ film, thus rendering it suitable for use as a CE. The proportion of SWCNTs required for making such composite films is extremely low, and the monomer baths are highly reusable (when stored at $\sim 3-5{ }^{\circ} \mathrm{C}$ ), thus making this process economically viable as well. Other examples include composites of conducting polymers with metal sulfides, such as poly(indole-5-carboxylic acid) (PICA) with $\mathrm{Cu}_{2} \mathrm{~S}$, wherein the metal sulfide will exhibit high electrocatalytic activity and the conducting polymer will show good electrical conductivity. This composite can be prepared by simply electro-polymerizing the monomer (indole-5-carboxylic acid) in the presence of presynthesized $\mathrm{Cu}_{2} \mathrm{~S}$ nanoparticles. The ensuing PICA/ $\mathrm{Cu}_{2} \mathrm{~S}$ composite films are again easy to fabricate and up-scalable to large areas if required, and their compositions can be optimized for CE application. The advantages of using composites with conducting polymers include the following: Conjugated polymers can be easily fabricated in the form of uniform thin films over FTO substrates. They are generally compatible with most of the carbon nanostructures such as reduced graphene oxide and CNTs, metal sulfides $\left(\mathrm{NiS}, \mathrm{Cu}_{2} \mathrm{~S}, \mathrm{CuS}, \mathrm{Cu}-\mathrm{Zn}-\mathrm{Se}-\right.$ $\mathrm{S}$, etc.), metal oxides (such as $\mathrm{MoO}_{3-x}$ ), and even metal nanoparticles $(\mathrm{Au}, \mathrm{Pt}$, etc.). They are highly stable in sulfide electrolyte. Therefore, composite formation to improve the catalytic activity of the conducting polymer with any of the above is facile and is expected to lead to cells with high performance. Some more possibilities are poly(3,4-ethylenedioxypyrrole) (PEDOP) with MWCNTs, PICA with RGO, PMP with NiS, CuS, or $\mathrm{MoO}_{3-x}$, and so forth. These directions can be adopted to develop many such novel composite films where the synergy between the two components can ameliorate the QDSC performance and which have not been applied to QDSCs until date.

\section{CONCLUSIONS}

The role of CE in controlling the performance of a QDSC has been demonstrated in this report by using nine different CEs: SWCNTs, $\mathrm{WO}_{3}, \mathrm{PEDOT}, \mathrm{Cu}_{2} \mathrm{~S}$, candle soot, F-MWCNTs, $\mathrm{WO}_{3-x}$, C-Fabric, and C-Fabric/ $\mathrm{WO}_{3-x}$. QDSCs were constructed with $\mathrm{TiO}_{2} / \mathrm{CdS}$ photoanodes and a polysulfide electrolyte. In a QDSC, the efficacy of a CE is a direct measure of the effectiveness of the reduction process of the polysulfide species at the $\mathrm{CE} /$ electrolyte interface, which then regenerates the QDs. How effective the CEs were in catalyzing this reduction was reflected in the PCEs of the cells based on the 
aforesaid CEs: 2.02, 2.1, 2.79, 2.88, 2.95, 3.78, 3.66, 3.96, and $4.6 \%$ respectively. The variation of IPCEs with wavelength for the cells was observed to concur with the PCE trend. Among all the CEs, the C-Fabric/ $/ \mathrm{WO}_{3-x}$-based cell exhibited the highest PCE, and this was attributed to the least polysulfide reduction potential, a reasonably good electrocatalytic activity (evidenced from the highest reduction peak current density), and a low sheet resistance of the C-Fabric and its meshlike morphology that maximized $\mathrm{WO}_{3-x}$ loading. Solely $\mathrm{WO}_{3-x}$-based cell showed a high FF and $V_{\mathrm{OC}}>1 \mathrm{~V}$, and this aided in improving the $\mathrm{FF}$ of the cell with the $\mathrm{C}-\mathrm{Fabric} / \mathrm{WO}_{3-x} \mathrm{CE}$. Most of the carbon nanostructures based and $\mathrm{Cu}_{2} \mathrm{~S}$ based $\mathrm{CEs}$ yielded moderately high PCEs when used in QDSCs. This study showed that $\mathrm{WO}_{3}$-based electrodes, particularly oxygendeficient $\mathrm{WO}_{3-x}$, can serve as efficient CEs in QDSCs. Concepts to design novel conducting polymer composites based CEs are also discussed, and we expect this report to be of great significance for developing QDSCs with high efficiencies.

\section{ASSOCIATED CONTENT}

\section{S Supporting Information}

The Supporting Information is available free of charge on the ACS Publications website at DOI: 10.1021/acsami.6b08921.

Tables of emission decay parameters and solar cell parameters (from this work and from literature) (PDF)

\section{AUTHOR INFORMATION}

\section{Corresponding Author}

*E-mail: mdeepa@iith.ac.in. Tel.: +91-40-23016024. Fax: +9140-23016003.

Notes

The authors declare no competing financial interest.

\section{ACKNOWLEDGMENTS}

Financial support from the Solar Energy Research InitiativeDepartment of Science \& Technology (DST/TM/SERI/2K12$11(\mathrm{G}))$ is gratefully acknowledged. P.N.K. and A.K. are thankful to UGC for senior and junior research fellowships, respectively.

\section{REFERENCES}

(1) Du, J.; Du, Z.; Hu, J. S.; Pan, Z.; Shen, Q.; Sun, J.; Long, D.; Dong, H.; Sun, L.; Zhong, X.; Wan, L.-J. Zn-Cu-In-Se Quantum Dot Solar Cells with a Certified Power Conversion Efficiency of 11.6\%. J. Am. Chem. Soc. 2016, 138 (12), 4201-4209.

(2) Ren, Z.; Wang, J.; Pan, Z.; Zhao, K.; Zhang, H.; Li, Y.; Zhao, Y.; Mora-Sero, I.; Bisquert, J.; Zhong, X. Amorphous TiO2 Buffer Layer Boosts Efficiency of Quantum Dot Sensitized Solar Cells to over 9\%. Chem. Mater. 2015, 27 (24), 8398-8405.

(3) Chen, H.; Zhu, L.; Liu, H.; Li, W. Efficient Iron Sulfide Counter Electrode for Quantum Dots-Sensitized Solar Cells. J. Power Sources 2014, 245, 406-410.

(4) Zhao, K.; Yu, H.; Zhang, H.; Zhong, X. Electroplating Cuprous Sulfide Counter Electrode for High-Efficiency Long-Term Stability Quantum Dot Sensitized Solar Cells. J. Phys. Chem. C 2014, 118, $5683-5690$.

(5) Radich, J. G.; Dwyer, R.; Kamat, P. V. Cu2S Reduced Graphene Oxide Composite for High-Efficiency Quantum Dot Solar Cells. Overcoming the Redox Limitations of $\mathrm{S}^{-2} / \mathrm{Sn}^{2-}$ at the Counter Electrode. J. Phys. Chem. Lett. 2011, 2, 2453-2460.

(6) Shen, C.; Sun, L.; Koh, Z. Y.; Wang, Q. Cuprous Sulfide Counter Electrodes Prepared by Ion Exchange for High-Efficiency Quantum Dot- Sensitized Solar Cells. J. Mater. Chem. A 2014, 2, 2807-2813.
(7) Chen, H.; Zhu, L.; Liu, H.; Li, W. ITO Porous Film-Supported Metal Sulfides Counter Electrodes for High Performance Quantum Dots-Sensitized Solar Cells. J. Phys. Chem. C 2013, 117, 3739-3746.

(8) Santra, P. K.; Kamat, P. V. Tandem Layered Quantum Dot Solar Cells. Tuning the Photovoltaic Response with Luminescent Ternary Cadmium Chalcogenides. J. Am. Chem. Soc. 2013, 135, 877-885.

(9) Kaniyoor, A.; Ramaprabhu, S. Gold Nanoparticle Decorated Multi-Walled Carbon Nanotubes as Counter Electrode for Dye Sensitized Solar Cells. J. Nanosci. Nanotechnol. 2012, 12, 8323-8329.

(10) Dao, V. D.; Hoa, N. T. Q.; Larina, L. L.; Lee, J. K.; Choi, H. S. Graphene-Platinum Nanohybrid as a Robust and Low-Cost Counter Electrode for Dye-Sensitized Solar Cells. Nanoscale 2013, 5 (24), 12237-12244.

(11) Cao, Y.; Xiao, Y.; Jung, J. Y.; Um, H. D.; Jee, S. W.; Choi, H. M.; Bang, J. H.; Lee, J. H. Highly Electrocatalytic CuZnSn $\left(\mathrm{S}_{1-x} \mathrm{Se}_{\mathrm{x}}\right)_{4}$ Counter Electrodes for Quantum-Dot-Sensitized Solar Cells. ACS Appl. Mater. Interfaces 2013, 5 (3), 479-484.

(12) Milan, R.; Hassan, M.; Selopal, G. S.; Borgese, L.; Natile, M. M.; Depero, L. E.; Sberveglieri, G.; Concina, I. A Player Often Neglected: Electrochemical Comprehensive Analysis of Counter Electrodes for Quantum Dot Solar Cells. ACS Appl. Mater. Interfaces 2016, 8 (12), 7766-7776.

(13) Tachan, Z.; Shalom, M.; Hod, I.; Rühle, S.; Tirosh, S.; Zaban, A. $\mathrm{PbS}$ as a Highly Catalytic Counter Electrode for Polysulfide Based Quantum Dot Solar Cells. J. Phys. Chem. C 2011, 115, 6162-6166.

(14) Xu, J.; Yang, X.; Wong, T. L.; Lee, C. S. Large-Scale Synthesis of $\mathrm{Cu}_{2} \mathrm{SnS}_{3}$ and $\mathrm{Cu}_{1.8 \mathrm{~S}}$ Hierarchical Microspheres as Efficient Counter Electrode Materials for Quantum Dot Sensitized Solar Cells. Nanoscale 2012, 4 (20), 6537-6542.

(15) Jun, H. K.; Careem, M. A.; Arof, A. K. Performances of Some Low-Cost Counter Electrode Materials in CdS and CdSe Quantum Dot-Sensitized Solar Cells. Nanoscale Res. Lett. 2014, 9 (1), 69-76.

(16) Ren, Z.; Wang, J.; Pan, Z.; Zhao, K.; Zhang, H.; Li, Y.; Zhao, Y.; Mora-Sero, I.; Bisquert, J.; Zhong, X. Amorphous TiO2 Buffer Layer Boosts Efficiency of Quantum Dot Sensitized Solar Cells to over 9\%. Chem. Mater. 2015, 27, 8398-8405.

(17) Zhao, K.; Pan, Z.; Mora-Seró, I.; Cánovas, E.; Wang, H.; Song, Y.; Gong, X.; Wang, J.; Bonn, M.; Bisquert, J.; Zhong, X. Boosting Power Conversion Efficiencies of Quantum-Dot-Sensitized Solar Cells Beyond $8 \%$ by Recombination Control. J. Am. Chem. Soc. 2015, 137, $5602-5609$.

(18) Meng, K.; Chen, G.; Thampi, K. R. Metal Chalcogenides as Counter Electrode Materials in Quantum Dot Sensitized Solar Cells: A Perspective. J. Mater. Chem. A 2015, 3, 23074-23089.

(19) Hwang, I.; Yong, K. Counter Electrodes for Quantum-DotSensitized Solar Cells. ChemElectroChem 2015, 2 (5), 634-653.

(20) Hod, I.; Zaban, A. Materials and Interfaces in Quantum Dot Sensitized Solar Cells: Challenges, Advances and Prospects. Langmuir 2014, 30 (25), 7264-7273.

(21) Yuan, H. L.; Lu, J. F.; Xu, X. B.; Huang, D. K.; Chen, W.; Shen, Y.; Wang, M. K. Electrochemically Deposited CoS Films as Counter Electrodes for Efficient Quantum Dot-Sensitized Solar Cells. J. Electrochem. Soc. 2013, 160 (9), H624-H629.

(22) Kumar, P. N.; Deepa, M.; Srivastava, A. K. Ag Plasmonic Nanostructures and a Novel Gel Electrolyte in a High Efficiency $\mathrm{TiO}_{2} /$ CdS Solar Cell. Phys. Chem. Chem. Phys. 2015, 17 (15), 10040-10052.

(23) Worsley, K. A.; Kalinina, I.; Bekyarova, E.; Haddon, R. C. Functionalization and Dissolution of Nitric Acid Treated SingleWalled Carbon Nanotubes. J. Am. Chem. Soc. 2009, 131 (50), 1815318158.

(24) Shalom, M.; Dor, S.; Rühle, S.; Grinis, L.; Zaban, A. Core/CdS Quantum Dot/Shell Mesoporous Solar Cells with Improved Stability and Efficiency Using an Amorphous $\mathrm{TiO}_{2}$ Coating. J. Phys. Chem. C 2009, 113, 3895-3898.

(25) Milekhin, A. G.; Yeryukov, N. A.; Sveshnikova, L. L.; Duda, T. A.; Rodyakina, E. E.; Gridchin, V. A.; Sheremet, E. S.; Zahn, D. R. T. Combination of Surface- and Interference-Enhanced Raman Scattering by $\mathrm{CuS}$ Nanocrystals on Nanopatterned Au Structures. Beilstein J. Nanotechnol. 2015, 6, 749-754. 
(26) Santato, C.; Odziemkowski, M.; Ulmann, M.; Augustynski, J. Crystallographically Oriented Mesoporous $\mathrm{WO}_{3}$ Films: Synthesis, Characterization, and Applications. J. Am. Chem. Soc. 2001, 123, 10639-10649.

(27) White, C. M.; Jang, S.; Lee, H.; Pankow, J.; Dillon, A. C. Photocatalytic Activity and Photoelectrochemical Property of Nano$\mathrm{WO}_{3}$ Powders Made by Hot-Wire Chemical Vapor Deposition. Electrochem. Solid-State Lett. 2010, 13, B120-B122.

(28) Garreau, S.; Louarn, G.; Buisson, J. P.; Froyer, G.; Lefrant, S. In Situ Spectroelectrochemical Raman Studies of Poly (3, 4-Ethylenedioxythiophene) (PEDT). Macromolecules 1999, 32, 6807-6812.

(29) Xia, Y.; Zhang, H.; Ouyang, J. Highly Conductive PEDOT: PSS Films Prepared through a Treatment with Zwitterions and Their Application in Polymer Photovoltaic Cells. J. Mater. Chem. 2010, 20, 9740-9747.

(30) Gao, W.; Alemany, L. B.; Ci, L.; Ajayan, P. M. New Insights into the Structure and Reduction of Graphite Oxide. Nat. Chem. 2009, 1 (5), 403-408.

(31) Li, Y. S.; Liao, J. L.; Wang, S. Y.; Chiang, W. H. Intercalationassisted longitudinal unzipping of carbon nanotubes for green and scalable synthesis of graphene nanoribbons. Sci. Rep. 2016, 6, 22755.

(32) Wang, S.; Yang, S. Growth of Crystalline $\mathrm{Cu}_{2} \mathrm{~S}$ Nanowire Arrays on Copper Surface: Effect of Copper Surface Structure, Reagent Gas Composition, and Reaction Temperature. Chem. Mater. 2001, 13, 4794-4799.

(33) Bhandari, S.; Deepa, M.; Srivastava, A. K.; Kant, R. PostPolymerization Functionalization of poly(3,4-Ethylenedioxythiophene) Films by 1-Fluoro-2-Nitro-4-Azidobenzene: Electrochromism and Redox Behavior. J. Mater. Chem. 2009, 19 (16), 2336-2348.

(34) Deng, M.; Huang, S.; Zhang, Q.; Li, D.; Luo, Y.; Shen, Q.; Toyoda, T.; Meng, Q. Screen-Printed $\mathrm{Cu}_{2} \mathrm{~S}$-Based Counter Electrode for Quantum-Dot-Sensitized Solar Cell. Chem. Lett. 2010, 39 (84), $1168-1170$.

(35) Tathavadekar, M.; Biswal, M.; Agarkar, S.; Giribabu, L.; Ogale, S. Electronically and Catalytically Functional Carbon Cloth as a Permeable and Flexible Counter Electrode for Dye Sensitized Solar Cell. Electrochim. Acta 2014, 123, 248-253.

(36) Song, D.; Chen, Z.; Cui, P.; Li, M.; Zhao, X.; Li, Y.; Chu, L. $\mathrm{NH} 3$-Treated $\mathrm{WO}_{3}$ as Low-Cost and Efficient Counter Electrode for Dye-Sensitized Solar Cells. Nanoscale Res. Lett. 2015, 10, 1-6.

(37) Zeng, X.; Xiong, D.; Zhang, W.; Ming, L.; Xu, Z.; Huang, Z.; Wang, M.; Chen, W.; Cheng, Y. B. Spray Deposition of Water-Soluble Multiwall Carbon Nanotube and $\mathrm{Cu}_{2} \mathrm{ZnSnSe}_{4}$ Nanoparticle Composites as Highly Efficient Counter Electrodes in a Quantum DotSensitized Solar Cell System. Nanoscale 2013, 5 (15), 6992-6998.

(38) Yeh, M. H.; Lee, C. P.; Chou, C. Y.; Lin, L. Y.; Wei, H. Y.; Chu, C. W.; Vittal, R.; Ho, K. C. Conducting Polymer-Based Counter Electrode for a Quantum-Dot-Sensitized Solar Cell (QDSSC) with a Polysulfide Electrolyte. Electrochim. Acta 2011, 57 (1), 277-284.

(39) Boschloo, G.; Hagfeldt, A. Characteristics of the Iodide/ Triiodide Redox Mediator in Dye-Sensitized Solar Cells. Acc. Chem. Res. 2009, 42 (11), 1819-1826. 